Published in final edited form as:

Inorg Chem. 2006 November 27; 45(24): 9748-9757.

\title{
Midrange Affinity Fluorescent Zn(II) Sensors of the Zinpyr Family: Syntheses, Characterization, and Biological Imaging Applications
}

\author{
Elizabeth M. Nolan ${ }_{*}$, Jacek Jaworski ${ }^{\ddagger}, \S, \perp$, Maryann E. Racine ${ }^{\dagger}$, Morgan Sheng ${ }^{\ddagger}, \S, \|, \perp$, and \\ Stephen J. Lippard ${ }^{{ }^{*}, \dagger}$ \\ Departments of Chemistry and Brain and Cognitive Sciences, Picower Institute of Learning and \\ Memory, RIKEN-MIT Neuroscience Research Center, and Howard Hughes Medical Institute, \\ Massachusetts Institute of Technology, Cambridge, Massachusetts 02139
}

\begin{abstract}
The syntheses and photophysical characterization of ZP9, 2-\{2-chloro-6-hydroxy-3-oxo-5-[(2\{[pyridin-2-ylmethyl-(1H-pyrrol-2-ylmethyl)amino]methyl $\}$ phenylamino)methyl]-3H-xanthen-9yl\}benzoic acid, and ZP10, 2-\{2-chloro-6-hydroxy-5-[(2-\{[(1-methyl-1H-pyrrol-2-ylmethyl) pyridin-2-ylmethylamino]methyl \} phenylamino)methyl]-3-oxo-3H-xanthen-9-yl benzoic acid, two asymmetrically derivatized fluorescein-based dyes, are described. These sensors each contain an aniline-based ligand moiety functionalized with a pyridyl-amine-pyrrole group and have dissociation constants for Zn(II) in the sub-micromolar (ZP9) and low-micromolar (ZP10) range, which we define as "midrange". They give $\sim 12$ - (ZP9) and 7-fold (ZP10) fluorescence turn-on immediately following $\mathrm{Zn}$ (II) addition at neutral $\mathrm{pH}$ and exhibit improved selectivity for $\mathrm{Zn}$ (II) compared to the di-(2-picolyl)amine-based Zinpyr (ZP) sensors. Confocal microscopy studies indicate that such asymmetrical fluorescein-based probes are cell permeable and $\mathrm{Zn}(\mathrm{II})$ responsive in vivo.
\end{abstract}

\section{Introduction}

Many factors determine the performance of small molecule sensors in vivo, including their photophysical properties, sensitivity, and selectivity for the analyte of interest, affinity for the analyte and other species in the biological milieu, and behavior and localization within cells or tissues. Some of these features, such as emission profiles and binding affinity, are relatively easy to control, whereas those pertaining to performance in a given biological sample often cannot be readily anticipated prior to a first series of experiments. The work described here focuses on several of these issues in the context of fluorescent $\mathrm{Zn}$ (II) sensor design and biological application.

It is of general interest to procure $\mathrm{Zn}$ (II) sensors that have similar photophysical properties and span a range of dissociation constants. ${ }^{1-6}$ Such molecules are invaluable for studies in neurobiology, where estimated concentrations of $\mathrm{Zn}$ (II) range from pico- to sub-millimolar depending on the cell type and phenomena under investigation. ${ }^{7-9}$ Many small-molecule $\mathrm{Zn}$ (II) sensors use the di-(2-picolyl)amine (DPA) ligand fragment, ${ }^{10-28}$ which affords selectivity for $\mathrm{Zn}(\mathrm{II})$ over high concentrations of $\mathrm{K}(\mathrm{I}), \mathrm{Na}(\mathrm{I}), \mathrm{Ca}(\mathrm{II})$, and $\mathrm{Mg}(\mathrm{II})$ and is therefore suitable for biological work. Because DPA itself binds $\mathrm{Zn}$ (II) with nanomolar affinity at $\mathrm{pH} 7,29,30$ alternative $\mathrm{Zn}$ (II)-binding frameworks are required to raise the apparent dissociation constant

\footnotetext{
* To whom correspondence should be addressed. E-mail: lippard@mit.edu.

Department of Chemistry.

Department of Brain and Cognitive Sciences.

\$Picower Institute of Learning and Memory.

||RIKEN-MIT Neuroscience Research Center.

Howard Hughes Medical Institute.
} 
$\left(K_{\mathrm{d}}\right)$. Several strategies have been employed to achieve this objective. A series of ratiometric probes that employ the benzimidazole reporting group were described in which the $\mathrm{Zn}$ (II) binding affinity was tuned over the sub-picomolar to micromolar range. ${ }^{5}$ Systematic modification of the DPA-based ligand employed in ZnAF-1 and ZnAF-2 afforded a sensor family with similar photophysical properties, fast association rates, and dissociation constants for $\mathrm{Zn}(\mathrm{II})$ that vary by approximately 6 orders of magnitude. ${ }^{6}$ Substitution of the pyridyl groups in Zinpyr- ${ }^{19}$ with 6-methylpyridyl moieties effectively raised the apparent ZP1/Zn(II) $K_{\mathrm{d} 1}$ value from the sub-nanomolar to the sub-micromolar. ${ }^{31}$ Other departures from the DPA ligand were incorporated in the design of the Zinspy $(\mathrm{ZS})^{32}$ and $\mathrm{QZ}^{33}$ sensor families; the latter probes exhibit micromolar dissociation constants. Modulation of $\mathrm{Zn}$ (II) affinity has also been considered in the design of protein- ${ }^{2}$ and peptide-based sensors. ${ }^{4}$ Several of these probes have been employed for biological imaging and provide definitive proof that binding affinity is an important parameter for in vivo $\mathrm{Zn}(\mathrm{II})$ detection. 6,33

Our laboratory has prepared fluorescein-based Zn(II) sensors with a single Zn(II) binding unit installed on the xanthene moiety (Figure 1). $11,26,27,32,33$ In the present work, we have modified the sensor platform of ZP4, 1 , through pyrrole-forpyridyl substitution and have evaluated the effects of this variation on both the photophysical and metal-binding properties. We anticipated that incorporation of pyrrole or $N$-methylpyrrole, both of which are poor bases, would raise the $\mathrm{Zn}$ (II) dissociation constant relative to that of the parent compound ZP4 ( $K_{\mathrm{d}}=$ $0.65 \mathrm{nM}$ ), which contains the DPA chelate, while maintaining similar fluorescence properties. Sensors ZP9, 2, and ZP10, 3, (Scheme 1) give fluorescence enhancement immediately following $\mathrm{Zn}$ (II) coordination, have dissociation constants for $\mathrm{Zn}$ (II) in the sub- (ZP9) to lowmicromolar (ZP10) range, and exhibit improved metal-binding selectivity for Zn(II) compared to DPA-based $\mathrm{ZP}^{21}$ and thioether-containing $\mathrm{ZS}$ sensors. ${ }^{32} \mathrm{We}$ also investigated the utility of aniline-based ZP probes for select biological imaging applications. On the basis of previous investigations with ZP4, which revealed that it selectively stains dead or damaged neurons, thereby suggesting cell impermeability, 21,34 we expected that ZP9 and ZP10 would also be cell impermeable without modification. Preliminary observations indicated otherwise, and an account of our more detailed cellular studies with ZP9 and ZP4 is provided here.

\section{Experimental Section}

\section{Reagents}

Acetonitrile was purged with $\mathrm{Ar}$ and dried by passage through columns of $\mathrm{Al}_{2} \mathrm{O}_{3}$. Anhydrous EtOAc and 1,2-dichloroethane (DCE) were purchased from Aldrich and used as received. In preparation for the syntheses of amines $\mathbf{4}$ and $\mathbf{5}$, ethanol and methanol were dried over $\mathrm{MgSO}_{4} \cdot N$-(2-Pyridylmethyl)- $N$-(1H-2-pyrrolylmethyl)amine, ${ }^{35} \mathbf{4}$, and $7^{\prime}$-chloro-4' fluoresceincarboxaldehyde, ${ }^{26} 6$, were synthesized according to literature procedures. All other reagents were obtained from Aldrich and used as received.

\section{General Methods}

Analytical TLC was performed on Merck F254 silica gel plates, Merck F254 aluminum oxide plates, or octadecyl-functionalized (reverse phase, RP18) plates ( $0.25 \mathrm{~mm}$ thickness). Reversephase plates of $1 \mathrm{~mm}$ thickness manufactured by EM Science were used for preparative TLC. NMR spectra were obtained on a Varian $300 \mathrm{MHz}$ spectrophotometer operating at ambient probe temperature, $283 \mathrm{~K}$. Both ${ }^{1} \mathrm{H}$ and ${ }^{13} \mathrm{C}$ NMR spectra were referenced to internal probe standards. An Avatar FTIR instrument was used to obtain IR spectra. High-resolution mass spectrometry was performed by staff at the MIT Department of Chemistry Instrumentation Facility. 


\section{(2-Nitrobenzyl)pyridin-2-ylmethyl-(1 H-pyrrol-2-ylmethyl)-amine (7)}

Portions of 2-nitrobenzylbromide ( $533 \mathrm{mg}, 2.47 \mathrm{mmol}$ ), 4 (502 mg, $2.47 \mathrm{mmol}$ ), $\mathrm{K}_{2} \mathrm{CO}_{3}$ (400 $\mathrm{mg}, 2.89 \mathrm{mmol}$ ), and activated $3 \AA$ molecular sieves were combined in $20 \mathrm{~mL}$ of $\mathrm{MeCN}$ and stirred vigorously overnight at room temperature. The reaction mixture was filtered through Celite, and the solvent was removed under reduced pressure to yield a brown-yellow oil. The crude product was flushed through a plug of $\mathrm{Al}_{2} \mathrm{O}_{3}\left(5: 1 \mathrm{CH}_{2} \mathrm{Cl}_{2} / \mathrm{EtOAc}\right)$, which yielded a lightyellow solid (730 mg, 91\%). TLC: $R_{f}=0.58\left(\mathrm{Al}_{2} \mathrm{O}_{3}, 2: 1\right.$ hexanes/EtOAc). mp: $85-86{ }^{\circ} \mathrm{C} .{ }^{1} \mathrm{H}$ NMR ( $\left.\mathrm{CDCl}_{3}, 300 \mathrm{MHz}\right): \delta 3.42(2 \mathrm{H}, \mathrm{s}), 3.68(2 \mathrm{H}, \mathrm{s}), 4.00(2 \mathrm{H}, \mathrm{s}) 6.04(1 \mathrm{H}, \mathrm{m}), 6.19(1 \mathrm{H}, \mathrm{m})$, $6.88(1 \mathrm{H}, \mathrm{m}), 7.21(1 \mathrm{H}, \mathrm{m}), 7.33-7.43(2 \mathrm{H}, \mathrm{m}), 7.44-7.53(2 \mathrm{H}, \mathrm{m}), 7.54-7.77(2 \mathrm{H}, \mathrm{m}), 8.56$ $(1 \mathrm{H}, \mathrm{dq}), 9.98(1 \mathrm{H}, \mathrm{br} \mathrm{s}) .{ }^{13} \mathrm{C} \mathrm{NMR}\left(\mathrm{CDCl}_{3}, 125 \mathrm{MHz}\right): 848.06,55.69,58.85,107.64,108.52$, $117.88,122.43,124.30,124.85,126.87,128.16,131.38,132.07,134.25,136.92,148.35$, 150.34, 158.51. FTIR (KBr, cm $\left.{ }^{-1}\right): 3426(\mathrm{~m}), 3198(\mathrm{w}), 3077$ (w), $2970(\mathrm{w}), 2920(\mathrm{~m}), 1595$ (m), $1570(\mathrm{~m}), 1528(\mathrm{~s}), 1470(\mathrm{~m}), 1442(\mathrm{~m}), 1431(\mathrm{~m}), 1413(\mathrm{w}), 1362(\mathrm{~s}), 1300(\mathrm{w}), 1259$ (w), $1243(\mathrm{w}), 1231(\mathrm{w}), 1151(\mathrm{w}), 1132(\mathrm{w}), 1114(\mathrm{~m}), 1103(\mathrm{~m}), 1079(\mathrm{w}), 1051(\mathrm{w}), 1029$ (w), $1001(\mathrm{w}), 991(\mathrm{~m}), 965(\mathrm{w}), 952(\mathrm{w}), 884(\mathrm{~m}), 866(\mathrm{w}), 812(\mathrm{~m}), 782(\mathrm{~m}), 768(\mathrm{~m}), 732$ (s), $676(\mathrm{~s}), 632(\mathrm{w}), 610(\mathrm{w})$. HRMS (ESI): calcd [M + Na] ${ }^{+}, 345.1322$; found, 345.1338.

\section{2-\{[Pyridin-2-ylmethyl-(1 H-pyrrol-2-ylmethyl)amino]methyl\}-phenylamine (8)}

A flask containing $\mathrm{Pd} / \mathrm{C}$ (10\% activated, $180 \mathrm{mg}$ ) was purged with $\mathrm{Ar}$, and $10 \mathrm{~mL}$ of $\mathrm{MeOH}$ was added. A portion (101 $\mathrm{mg}, 0.313 \mathrm{mmol}$ ) of 7 dissolved in $15 \mathrm{~mL}$ of $\mathrm{MeOH}$ was added, and a balloon filled with $\mathrm{H}_{2}$ was attached. The reaction mixture was stirred vigorously under $\mathrm{H}_{2}$ for $2.5 \mathrm{~h}$, purged with Ar, and filtered through Celite before the solvent was removed under reduced pressure. Flash chromatography on $\mathrm{Al}_{2} \mathrm{O}_{3}$ using a solvent gradient (10:1-4:1

$\mathrm{CH}_{2} \mathrm{Cl}_{2} / \mathrm{EtOAc}$ with $1 \% i \mathrm{PrNH}_{2}$ ) yielded the purified product as a brown oil (48 $\mathrm{mg}, 52 \%$ ). TLC: $R_{f}=0.43\left(\mathrm{Al}_{2} \mathrm{O}_{3}, 2: 1\right.$ hexanes/EtOAc). $\left.1 \mathrm{H} \mathrm{NMR} \mathrm{(CDCl} 3,300 \mathrm{MHz}\right): \delta 3.57(2 \mathrm{H}, \mathrm{s}), 3.69$ $(2 \mathrm{H}, \mathrm{s}), 3.71(2 \mathrm{H}, \mathrm{s}), 4.95(2 \mathrm{H}, \mathrm{br} \mathrm{s}), 6.07(1 \mathrm{H}, \mathrm{m}), 6.18(1, \mathrm{~m}), 6.67(2 \mathrm{H}, \mathrm{m}), 6.85(1 \mathrm{H}, \mathrm{m})$, $7.09(2 \mathrm{H}, \mathrm{m}), 7.32(2 \mathrm{H}, \mathrm{m}), 7.69(1 \mathrm{H}, \mathrm{td}), 8.62(1 \mathrm{H}, \mathrm{dq}), 10.23(1 \mathrm{H}, \mathrm{br} \mathrm{s}) .{ }^{13} \mathrm{C} \mathrm{NMR}\left(\mathrm{CDCl}_{3}\right.$, $125 \mathrm{MHz}): \delta 47.92,58.02,58.10,107.77,108.33,115.73,117.48,117.64,122.41,122.57$, 124.61, 127.36, 128.47, 130.93, 136.86, 147.05, 148.75, 158.84. FTIR ( $\mathrm{NaCl}$ disk, $\left.\mathrm{cm}^{-1}\right): 3403$ (m), $3298(\mathrm{~m}), 3092(\mathrm{w}), 3011(\mathrm{w}), 2922(\mathrm{w}), 2832(\mathrm{~m}), 1656(\mathrm{w}), 1614(\mathrm{~s}), 1592(\mathrm{~s}), 1569$ (m), $1494(\mathrm{~s}), 1475(\mathrm{~m}), 1461(\mathrm{~m}), 1435(\mathrm{~m}), 1405(\mathrm{w}), 1366(\mathrm{~m}), 1339(\mathrm{w}), 1315(\mathrm{w}), 1297$ (w), $1284(\mathrm{w}), 1261(\mathrm{w}), 1236(\mathrm{w}), 1150(\mathrm{~m}), 1114(\mathrm{~m}), 1091(\mathrm{~m}), 1049(\mathrm{w}), 1027(\mathrm{~m}), 997$ (w), $980(w), 970(w), 956(w), 926(w), 884(w), 841(w), 801(\mathrm{~m}), 751(\mathrm{~s}), 720(\mathrm{~s}), 640(\mathrm{w})$, $615(w), 560(w), 540(w), 500(w)$. HRMS (ESI): calcd [M + Na] $]^{+}, 315.1580$; found, 315.1575.

\section{2-\{2-Chloro-6-hydroxy-3-oxo-5-[(2-\{[pyridin-2-ylmethyl-(1 H-pyrrol-2-ylmethyl)amino] methyl\}phenylamino)methyl]-3H-xanthen-9-yl\}benzoic Acid (2, Zinpyr-9, ZP9)}

Portions of $8(75 \mathrm{mg}, 0.25 \mathrm{mmol})$ and $\mathbf{6}(72 \mathrm{mg}, 0.26 \mathrm{mmol})$ were combined in $10 \mathrm{~mL}$ of EtOAc, and the mixture was stirred overnight at room temperature. The solution turned deep red. The solvent was removed under reduced pressure, and the red residue, intermediate $\mathbf{9}$, was suspended in $5 \mathrm{~mL}$ of 1,2-dichloroethane. A portion (160 mg, $0.754 \mathrm{mmol})$ of $\mathrm{NaB}(\mathrm{OAc})_{3} \mathrm{H}$ was added, and the reaction mixture was stirred at room temperature. The solution became clear and light orange over the course of $3 \mathrm{~h}$. Preparative TLC on reverse phase silica gel (6:1 $\mathrm{MeOH} / 0.1 \mathrm{~N} \mathrm{HCl}$ ) yielded the pure product as a red solid (42 mg, 33\%). This material can also be purified by preparative TLC on silica gel $\left(20: 1 \mathrm{CHCl}_{3} / \mathrm{MeOH}\right)$. TLC: $R_{f}=0.41$ (RP silica, 6:1 MeOH/0.1 N HCl). $\mathrm{mp}(\mathrm{dec}):>325{ }^{\circ} \mathrm{C} .{ }^{1} \mathrm{H}$ NMR $\left(\mathrm{CD}_{3} \mathrm{OD}, 300 \mathrm{MHz}\right): \delta 3.56-3.67(6 \mathrm{H}$, $\mathrm{m}), 4.57(2 \mathrm{H}, \mathrm{s}), 5.93(2 \mathrm{H}, \mathrm{d}), 6.63-6.73(4 \mathrm{H}, \mathrm{m}), 6.81(1 \mathrm{H}, \mathrm{s}), 6.99-7.24(6 \mathrm{H}, \mathrm{m}), 7.39(1 \mathrm{H}$, t), 7.71-7.83 (3H, m), $8.06(1 \mathrm{H}, \mathrm{d}), 8.26(1 \mathrm{H}, \mathrm{d})$. FTIR $\left(\mathrm{KBr}, \mathrm{cm}^{-1}\right): 3418(\mathrm{~s}), 3050(\mathrm{w}), 2920$ (m), $2850(\mathrm{~m}), 1761(\mathrm{~s}), 1632(\mathrm{~m}), 1606(\mathrm{~s}), 1582(\mathrm{~s}), 1516(\mathrm{~m}), 1490(\mathrm{~m}), 1451(\mathrm{~s}), 1368(\mathrm{~m})$, $1282(\mathrm{~s}), 1252(\mathrm{~m}), 1218(\mathrm{~m}), 1149(\mathrm{~s}), 1109(\mathrm{~m}), 1091(\mathrm{~m}), 1070(\mathrm{~m}), 1025(\mathrm{w}), 1008(\mathrm{~m})$, 
$874(\mathrm{w}), 834(\mathrm{w}), 798(\mathrm{w}), 751(\mathrm{~m}), 722(\mathrm{~m}), 702(\mathrm{~m}), 621(\mathrm{w}), 597(\mathrm{w}), 549(\mathrm{w}), 470(\mathrm{~m})$. HRMS (ESI): calcd [M -H] $]^{-}, 669.1910$; found, 669.1902.

\section{(1-Methyl-1 H-pyrrol-2-ylmethyl)pyridin-2-ylmethylamine (5)}

$\mathrm{N}$-Methyl-2-pyrrolecarboxaldehyde $(2.0 \mathrm{~g}, 18.3 \mathrm{mmol})$ was dissolved in $25 \mathrm{~mL}$ of EtOH with stirring. A portion $(2.0 \mathrm{~g}, 18.5 \mathrm{mmol})$ of 2-(aminomethyl)pyridine was added dropwise to the stirred solution, which was refluxed for $30 \mathrm{~min}$. The resulting yellow solution was cooled, and the solvent was removed in vacuo to yield an orange oil. The oil was dissolved in $40 \mathrm{~mL}$ of $\mathrm{MeOH}$, and the solution was cooled to $0^{\circ} \mathrm{C}$. A portion $(770 \mathrm{mg}, 20.5 \mathrm{mmol})$ of $\mathrm{NaBH}_{4}$ was added, and the reaction mixture was stirred at $0{ }^{\circ} \mathrm{C}$ for $30 \mathrm{~min}$ and then warmed to room temperature. After it was stirred for an additional $30 \mathrm{~min}$, the solution was heated to reflux for $4 \mathrm{~h}$ and cooled. The solvent was removed under reduced pressure, and the resulting yellowwhite residue was dissolved in $20 \mathrm{~mL}$ of water, which was extracted with $\mathrm{Et}_{2} \mathrm{O}(3 \times 20 \mathrm{~mL})$. The combined organics were dried over $\mathrm{MgSO}_{4}$, and the solvent was removed in vacuo, which yielded the product as a yellow oil $(3.1 \mathrm{~g}, 82 \%)$. TLC: $R_{f}=0.44$ (silica, 9:1 $\mathrm{CHCl}_{3} / \mathrm{MeOH}$ ). $1 \mathrm{H} \mathrm{NMR}\left(\mathrm{CDCl}_{3}, 300 \mathrm{MHz}\right): \delta 2.15(1 \mathrm{H}, \mathrm{br} \mathrm{s}), 3.64(3 \mathrm{H}, \mathrm{s}), 3.77(2 \mathrm{H}, \mathrm{s}), 3.93(2 \mathrm{H}, \mathrm{s}), 6.04$ $(2 \mathrm{H}, \mathrm{d}), 6.58(1 \mathrm{H}, \mathrm{t}), 7.16(1 \mathrm{H}, \mathrm{m}), 7.31(1 \mathrm{H}, \mathrm{d}), 7.64(1 \mathrm{H}, \mathrm{td}), 8.55(1 \mathrm{H}, \mathrm{dq}) .{ }^{13} \mathrm{C}$ NMR $\left(\mathrm{CDCl}_{3}, 125 \mathrm{MHz}\right): \delta 33.87,45.05,54.50,106.56,108.28,122.04,122.46,122.50,130.95$, 136.53, 149.37, 159.97. FTIR (NaCl disk, $\mathrm{cm}^{-1}$ ): 3315 (m, br), 3090 (w), 3064 (w), 3007 (m), $2920(\mathrm{~m}), 2828(\mathrm{~m}), 1591(\mathrm{~s}), 1569(\mathrm{~s}), 1496(\mathrm{~s}), 1473(\mathrm{~s}), 1456(\mathrm{~m}), 1433(\mathrm{~s}), 1416(\mathrm{~m}), 1356$ (w), $1325(\mathrm{w}), 1300$ (s), $1261(\mathrm{w}), 1215(\mathrm{w}), 1182(\mathrm{w}), 1170(\mathrm{w}), 1147$ (w), $1113(\mathrm{~m}), 1088$ (s), $1049(\mathrm{~m}), 1014(\mathrm{w}), 994(\mathrm{~m}), 955(\mathrm{w}), 938(\mathrm{w}), 917$ (w), $890(\mathrm{w}), 845$ (m), $794(\mathrm{~m}), 758$ (s), $710(\mathrm{~s}), 626(\mathrm{~m}), 611(\mathrm{~m})$. HRMS (ESI): calcd [M + Na] ${ }^{+}, 224.1158$; found, 224.1151.

\section{(1-Methyl-1 H-pyrrol-2-ylmethyl)-(2-nitrobenzyl)pyridin-2-yl-methylamine (10)}

2-Nitrobenzylbromide (1.07 g, $4.95 \mathrm{mmol}), \mathrm{K}_{2} \mathrm{CO}_{3}(1.36 \mathrm{~g}, 9.84 \mathrm{mmol}), \mathbf{5}(1.00 \mathrm{~g}, 4.97 \mathrm{mmol})$, and activated $3 \AA$ molecular sieves were combined in $50 \mathrm{~mL}$ of $\mathrm{MeCN}$, and the yellow solution was stirred vigorously at room temperature for $10 \mathrm{~h}$. The mixture was filtered through Celite, and the solvent was removed under reduced pressure. Chromatography on silica gel (2:1 hexanes/EtOAc) afforded the purified product as light yellow solid after drying in vacuo (1.50 g, 89\%). TLC: $R_{f}=0.32$ (silica, 1:1 hexanes/EtOAc). mp: $89-91^{\circ}$ C. ${ }^{1} \mathrm{H}$ NMR $\left(\mathrm{CDCl}_{3}, 300\right.$ $\mathrm{MHz}): \delta 3.42(3 \mathrm{H}, \mathrm{s}), 3.56(2 \mathrm{H}, \mathrm{s}), 3.68(2 \mathrm{H}, \mathrm{s}), 3.99(2 \mathrm{H}, \mathrm{s}), 5.99(1 \mathrm{H}, \mathrm{m}), 6.07(1 \mathrm{H}, \mathrm{m}), 6.53$ $(1 \mathrm{H}, \mathrm{m}), 7.12(1 \mathrm{H}, \mathrm{td}), 7.25(1 \mathrm{H}, \mathrm{m}), 7.34(1 \mathrm{H}, \mathrm{td}), 7.46(1 \mathrm{H}, \mathrm{td}), 7.50-7.63(2 \mathrm{H}, \mathrm{m}), 7.76(1 \mathrm{H}$, dd), $8.49(1 \mathrm{H}, \mathrm{dq}) .{ }^{13} \mathrm{C} \mathrm{NMR}\left(\mathrm{CDCl}_{3}, 125 \mathrm{MHz}\right): 833.78,51.15,55.85,60.71,106.53,110.43$, $122.13,122.94,123.43,124.41,128.00,128.59,131.81,132.35,134.58,136.40,148.88$, 150.06, 159.16. FTIR (KBr, cm $\left.{ }^{-1}\right): 3103$ (w), 3071 (w), 3006 (w), 2916 (w), 2878 (w), 2807 (m), $2792(\mathrm{~m}), 2722(\mathrm{w}), 1608(\mathrm{~m}), 1590(\mathrm{~m}), 1568(\mathrm{~m}), 1515(\mathrm{~s}), 1489(\mathrm{~m}), 1470(\mathrm{~m}), 1434$ (m), $1421(\mathrm{~m}), 1375(\mathrm{~m}), 1367(\mathrm{~m}), 1356(\mathrm{~m}), 1334(\mathrm{~s}), 1298(\mathrm{~s}), 1283(\mathrm{~m}), 1261(\mathrm{~m}), 1217$ (m), $1185(\mathrm{~m}), 1146(\mathrm{~m}), 1117(\mathrm{~s}), 1094(\mathrm{~m}), 1073(\mathrm{w}), 1047(\mathrm{~m}), 1013(\mathrm{w}), 1000(\mathrm{~m}), 983$ (m), $968(\mathrm{~m}), 954(\mathrm{~m}), 895(\mathrm{~m}), 886(\mathrm{w}), 871(\mathrm{w}), 856(\mathrm{w}), 847$ (w), $795(\mathrm{~m}), 764(\mathrm{~s}), 739(\mathrm{~s})$, 725 (s), 689 (m), 676 (w), 652 (w), 632 (w), 617 (m), 600 (w), 511 (w), $481(w), 436(w)$. HRMS (ESI): calcd [M + Na $]^{+}, 337.1659$; found, 337.1666 .

\section{2-\{[(1-Methyl-1H-pyrrol-2-ylmethyl)pyridin-2-ylmethylamino]-methyl\}phenylamine (11)}

Palladium on carbon (10\% activated, $900 \mathrm{mg}$ ) was placed in a flask purged with Ar. A $20 \mathrm{~mL}$ solution of $10(600 \mathrm{mg}, 1.78 \mathrm{mmol})$ in $19: 1 \mathrm{MeOH} / \mathrm{CH}_{2} \mathrm{Cl}_{2}$ was added with a syringe. The mixture was stirred vigorously, and a balloon of $\mathrm{H}_{2}$ was attached. After $1.5 \mathrm{~h}$ of stirring under $\mathrm{H}_{2}$, the reaction was purged with $\mathrm{Ar}$, filtered through Celite, and the solvents were removed under reduced pressure. Column chromatography on $\mathrm{Al}_{2} \mathrm{O}_{3}(2: 1-1: 1$ hexanes/EtOAc) yielded the purified product as an off-white solid ( $325 \mathrm{mg}, 60 \%)$. TLC: $R_{f}=0.47$ (silica, 2:1 hexanes/ EtOAc). mp: $105-109^{\circ} \mathrm{C} .{ }^{1} \mathrm{H}$ NMR $\left(\mathrm{CDCl}_{3}, 300 \mathrm{MHz}\right): \delta 3.40(3 \mathrm{H}, \mathrm{s}), 3.57(2 \mathrm{H}, \mathrm{s}), 3.61(2 \mathrm{H}$, 
s), $3.73(2 \mathrm{H}, \mathrm{s}), 4.53(2 \mathrm{H}, \mathrm{br} \mathrm{s}), 6.04(1 \mathrm{H}, \mathrm{t}), 6.12(1 \mathrm{H}, \mathrm{m}), 6.54(1 \mathrm{H}, \mathrm{m}), 6.11-6.73(2 \mathrm{H}, \mathrm{m})$, 7.06-7.20 (4H, m), $7.60(1 \mathrm{H}, \mathrm{td}), 8.56(1 \mathrm{H}, \mathrm{dq}) .{ }^{13} \mathrm{C} \mathrm{NMR}\left(\mathrm{CDCl}_{3}, 125 \mathrm{MHz}\right): 833.57,50.11$, $57.74,59.80,106.62,110.33,115.48,117.46,122.10,122.70,123.75,128.60,129.13,131.42$, 136.34, 146.80, 149.12, 159.57. FTIR (KBr, cm $\left.{ }^{-1}\right)$ : $3456(\mathrm{~s}), 3311(\mathrm{~m}), 3231(\mathrm{w}), 3199(\mathrm{w})$, $3022(\mathrm{w}), 2923(\mathrm{~m}), 2886(\mathrm{~m}), 2832(\mathrm{~m}), 2809(\mathrm{~m}), 1713(\mathrm{w}), 1630(\mathrm{~s}), 1605(\mathrm{~m}), 1591(\mathrm{~m})$, $1578(\mathrm{~m}), 1567(\mathrm{~m}), 1493(\mathrm{~s}), 1475(\mathrm{~m}), 1461(\mathrm{~m}), 1445(\mathrm{~m}), 1431(\mathrm{~m}), 1413(\mathrm{~m}), 1370(\mathrm{~m})$, $1358(\mathrm{~m}), 1326(\mathrm{~m}), 1310(\mathrm{~m}), 1298(\mathrm{~m}), 1267(\mathrm{~m}), 1250(\mathrm{w}), 1221(\mathrm{w}), 1207(\mathrm{w}), 1180(\mathrm{w})$, $1146(\mathrm{~m}), 1109(\mathrm{~m}), 1099(\mathrm{~m}), 1081(\mathrm{~m}), 1049(\mathrm{w}), 1035(\mathrm{w}), 997(\mathrm{~m}), 968(\mathrm{~m}), 954(\mathrm{~m}), 934$ (m), $897(\mathrm{w}), 887(\mathrm{w}), 869(\mathrm{~m}), 866(\mathrm{~m}), 837(\mathrm{w}), 790(\mathrm{~m}), 770(\mathrm{~m}), 752(\mathrm{~s}), 724(\mathrm{~s}), 682(\mathrm{w})$, 633 (w), $612(\mathrm{~m}), 548(\mathrm{w}), 516(\mathrm{~m}), 466$ (w), 444 (w), 410 (w). HRMS (ESI): calcd [M + $\mathrm{H}]^{+}$, 307.1917; found, 307.1915.

\section{2-\{2-Chloro-6-hydroxy-5-[(2-\{[(1-methyl-1H-pyrrol-2-ylmeth-yl)pyridin-2-ylmethylamino] methyl\}phenylamino)methyl]-3-oxo-3H-xanthen-9-yl\}benzoic Acid (3, Zinpyr-10, ZP10)}

Portions of 7' -chloro-4' -fluoresceincarboxaldehyde (6, 75 mg, $0.19 \mathrm{mmol})$ and 11 (58 mg, $0.19 \mathrm{mmol}$ ) were combined in $5 \mathrm{~mL}$ of EtOAc, and the mixture was stirred overnight at room temperature. The intermediate imine, $\mathbf{1 2}$, precipitated as a peach-colored solid, and the mixture was cooled on ice and filtered. The precipitate was suspended in $5 \mathrm{~mL}$ of DCE, and $\mathrm{NaB}$ $(\mathrm{OAc})_{3} \mathrm{H}(40 \mathrm{mg}, 0.19 \mathrm{mmol})$ was added. Over the course of $3 \mathrm{~h}$, the reaction became dark pink and clear and then turned light orange. Preparative TLC on reverse-phase silica gel (10:1 $\mathrm{MeOH} / 0.1 \mathrm{~N} \mathrm{HCl}$ ) yielded the product as an orange solid (38 mg, 29\%). $\mathrm{mp}(\mathrm{dec}):>300^{\circ}$ C. ${ }^{1} \mathrm{H}$ NMR $\left(\mathrm{CD}_{3} \mathrm{OD} / \mathrm{CDCl}_{3}, 300 \mathrm{MHz}\right): 83.12(3 \mathrm{H}, \mathrm{s}), 3.48-3.64(6 \mathrm{H}, \mathrm{m}), 4.45(2 \mathrm{H}, \mathrm{m}), 5.65$ $(1 \mathrm{H}, \mathrm{m}), 5.84(1 \mathrm{H}, \mathrm{m}), 6.23(1 \mathrm{H}, \mathrm{m}), 6.56-6.64(3 \mathrm{H}, \mathrm{m}), 6.97-7.12(4 \mathrm{H}, \mathrm{d}), 7.16-7.28(3 \mathrm{H}$, m), $7.29(1 \mathrm{H}, \mathrm{d}), 7.48(1 \mathrm{H}, \mathrm{td}), 7.60(2 \mathrm{H}, \mathrm{m}), 8.06(1 \mathrm{H}, \mathrm{m}), 8.24(1 \mathrm{H}, \mathrm{d})$. FTIR $\left(\mathrm{KBr}, \mathrm{cm}^{-1}\right)$ : 3425 (s, br), 3062 (w), 2963 (m), 2921 (s), 2851 (m), 1763 (s), 1628 (m), 1605 (s), 1583 (s), $1519(\mathrm{~m}), 1494(\mathrm{~m}), 1450(\mathrm{~s}), 1367(\mathrm{~m}), 1282(\mathrm{~s}), 1260(\mathrm{~s}), 1216(\mathrm{~m}), 1149(\mathrm{~m}), 1106(\mathrm{~m})$, $1089(\mathrm{~m}), 1070(\mathrm{~m}), 1011(\mathrm{~m}), 872(\mathrm{~m}), 797(\mathrm{~m}), 756(\mathrm{~m}), 702(\mathrm{~m}), 613(\mathrm{w}), 597(\mathrm{w}), 546(\mathrm{w})$, 509 (w), 470 (w), 409 (w). HRMS (ESI): calcd [M -H] ${ }^{-}, 683.2056$; found, 683.2047.

\section{2-(2-Chloro-6-hydroxy-3-oxo-5-phenylaminomethyl-3H-xan-then-9-yl)benzoic Acid (13)}

Fluorescein carboxaldehyde 6 (38 mg, $0.097 \mathrm{mmol})$ and aniline $(12 \mathrm{mg}, 0.13 \mathrm{mmol})$ were added to $3 \mathrm{~mL}$ of EtOAc, and the resulting orange solution was stirred overnight at room temperature. The solvent was removed under reduced pressure, which gave a red-magenta residue. The residue was dissolved in $5 \mathrm{~mL}$ of 1,2-dchloroethane, and $\mathrm{NaB}(\mathrm{OAc})_{3} \mathrm{H}(24 \mathrm{mg}$, $0.11 \mathrm{mmol}$ ) was added. The cloudy orange solution was stirred overnight at room temperature, diluted with $15 \mathrm{~mL}$ of $\mathrm{CHCl}_{3}$, washed with water $(3 \times 15 \mathrm{~mL})$, and dried in vacuo. Preparative TLC of the crude material on silica gel $\left(10: 1 \mathrm{CHCl}_{3} / \mathrm{MeOH}\right)$ gave pure 3 as a magenta solid (8.5 mg, 18\%). TLC: $R_{f}=0.53$ (silica, 9:1 $\mathrm{CHCl}_{3} / \mathrm{MeOH}$ ). $\mathrm{mp}$ (dec): $>300^{\circ} \mathrm{C} .{ }^{1} \mathrm{H} \mathrm{NMR}$ $\left(\mathrm{CD}_{3} \mathrm{OD}, 500 \mathrm{MHz}\right): \delta 4.48-4.59(2 \mathrm{H}, \mathrm{q}), 6.54(1 \mathrm{H}, \mathrm{d}), 6.61(1 \mathrm{H}, \mathrm{t}), 6.73(1 \mathrm{H}, \mathrm{m}), 6.86(2 \mathrm{H}$, d), $7.00(1 \mathrm{H}, \mathrm{d}), 7.08-7.13(3 \mathrm{H}, \mathrm{m}), 7.19(1 \mathrm{H}, \mathrm{d}), 7.56(2 \mathrm{H}, \mathrm{qd}), 8.03(1 \mathrm{H}, \mathrm{dd})$. FTIR $(\mathrm{KBr}$, $\mathrm{cm}^{-1}$ ): 3426 (m, br), $2960(\mathrm{~m}), 2924(\mathrm{~s}), 2854(\mathrm{~m}), 1728(\mathrm{w}), 1638(\mathrm{~m}), 1605(\mathrm{~m}), 1575(\mathrm{~m})$, $1503(\mathrm{~m}), 1461(\mathrm{~m}), 1376(\mathrm{~m}), 1341(\mathrm{~m}), 1301(\mathrm{~m}), 1261(\mathrm{~s}), 1222(\mathrm{w}), 1186(\mathrm{w}), 1147(\mathrm{~m})$, $1096(\mathrm{~m}), 1014(\mathrm{~m}), 963(\mathrm{w}), 936(\mathrm{w}), 881(\mathrm{w}), 823(\mathrm{~s}), 802(\mathrm{~s}), 749(\mathrm{~m}), 715(\mathrm{~m}), 690(\mathrm{~m})$, $662(\mathrm{w}), 623(\mathrm{~m}), 598(\mathrm{~m}), 547(\mathrm{~m}), 499(\mathrm{w})$. HRMS (ESI) calcd [M + H] $]^{+}, 472.0946$; found, 472.0930 .

\section{General Spectroscopic Procedures}

Millipore water was used to prepare all aqueous solutions. PIPES, piperazine- $N, N^{\prime}$-bis(2ethanesulfonic acid), and $99.999 \% \mathrm{KCl}$ were purchased from Calbiochem. Except for the $\mathrm{p} K_{\mathrm{a}}$ titrations, measurements were made at $\mathrm{pH} 7$ in $50 \mathrm{mM}$ PIPES, $100 \mathrm{mM} \mathrm{KCl}$ buffer. Rigorously treating this buffer with Chelex (BioRad, manufacturer protocol) to remove any 
potential metal-ion contamination had negligible effect on the emission and $\mathrm{Zn}$ (II) response of ZP9 and ZP10 compared to that observed in untreated buffer. Aqueous Zn(II) stock solutions $(100 \mathrm{mM})$ were prepared from anhydrous $99.999 \% \mathrm{ZnCl}_{2}$ obtained from Aldrich. DMSO stock solutions ( $1 \mathrm{mM}$ ) of ZP9 and ZP10 were prepared, partitioned, stored at $-25^{\circ} \mathrm{C}$, and thawed in the dark before use. After dilution to the appropriate concentration, solutions for spectroscopic measurements contained $0.1(1 \mu \mathrm{M}$ dye solution, fluorescence) to $1 \%(10 \mu \mathrm{M}$ dye solution, absorption) DMSO. A starting solution of $10 \mathrm{mM} \mathrm{KOH}$ and $100 \mathrm{mM} \mathrm{KCl}(\mathrm{pH}$ 12) was used for $\mathrm{pH}$ titrations. Quantum yields were measured relative to fluorescein in 0.1 $\mathrm{N} \mathrm{NaOH}(\Phi=0.95)^{36}$ with excitation provided at 497 (ZP9, ZP10), 496 (compound 13), 494 (Zn(II)-bound ZP10), or 493 (Zn(II)-bound ZP9) nm. Extinction coefficients were determined over a concentration range of $10-1 \mu \mathrm{M}$ for apo ZP9 and ZP10 and from 5-1 $\mu \mathrm{M}$ for the corresponding $\mathrm{Zn}(\mathrm{II})$ complexes because of limited solubility at higher concentrations. Metal ion selectivity experiments were conducted as previously described. ${ }^{26}$ Controls with ZP1, which preferentially binds Fe(II) over $\mathrm{Zn}$ (II), were conducted to test the aqueous $\mathrm{Fe}$ (II) solutions. All reported data are the averages of at least three independent measurements obtained using material from two independent syntheses. Further experimental details are available elsewhere. ${ }^{20,26}$

\section{Dissociation Constant Determination}

The apparent zinc dissociation constants for ZP9 and ZP10 were determined by fluori-metric analysis. In a typical experiment, a $1 \mu \mathrm{M}$ solution of the $\mathrm{ZP}$ compound was prepared $(50 \mathrm{mM}$ PIPES, $100 \mathrm{mM} \mathrm{KCl}, \mathrm{pH}$ 7, Chelexed), and its emission spectrum was recorded. Various aliquots of 1 or $10 \mathrm{mM}$ aqueous $\mathrm{ZnCl}_{2}$ solutions were added, and the emission changes were noted. Excitation was provided at $497 \mathrm{~nm}$, and the data were integrated from 505 to $650 \mathrm{~nm}$, normalized, and plotted against the total concentration of $\mathrm{Zn}(\mathrm{II})$ in solution. The data were fit to a $1: 1$ metal/ligand model. ${ }^{37}$

\section{Stopped-Flow Fluorescence Studies}

Single-mixing stopped-flow kinetics studies were performed with a Hi-Tech SF-61 DX2 double-mixing stopped-flow apparatus equipped with a fluorescence detector. Excitation was provided at $495 \mathrm{~nm}$, and a GG495 glass cutoff filter $(<455 \mathrm{~nm})$ was placed over the exit to the photomultiplier tube. Emission was monitored from 455 to $700 \mathrm{~nm}$. All solutions were prepared in $50 \mathrm{mM}$ PIPES, $100 \mathrm{mM} \mathrm{KCl}, \mathrm{pH}$ 7. Conditions for pseudo-first-order kinetics were maintained by using at least a 10 -fold excess of $\mathrm{Zn}$ (II) in all experiments. With the exception of the temperature-dependent studies, all measurements were conducted at $4.3 \pm 0.1^{\circ} \mathrm{C}$, maintained with a circulating bath. The temperature inside the sample chamber was monitored with an internal thermocouple. A series of control experiments were conducted where the initial $\mathrm{ZP}$ concentration was varied from 0.5 to $5 \mu \mathrm{M}$ after mixing to ensure that the observed rate constant was independent of initial dye concentration (data not shown). Multiple shots were taken for each $\mathrm{Zn}$ (II) concentration. Experiments were conducted a minimum of three times with different solutions, and the resulting averages are reported. The Kinet-Assyst software package (HiTech) was used to analyze the data. The observed rate constants were obtained by fitting individual traces to monoexponentials. Further experimental details are available in the Supporting Information and in ref 33 .

\section{Cell Culture}

Human embryonic kidney (HEK293-T, HEK) cells were plated on untreated glass coverslips coated with $0.2 \%$ gelatin for at least $1 \mathrm{~h}$ at room temperature and grown to $90 \%$ confluence in Dulbecco's modified eagle medium (DMEM) supplemented with 10\% FCS, glutamine (2 $\mathrm{mM})$, penicillin (100 units $/ \mathrm{mL})$, and streptomycin $(100 \mu \mathrm{g} / \mathrm{mL})$. The medium was removed and replaced with DMEM containing $1 \%$ serum prior to ZP treatment. DMSO stock solutions 
$(1 \mathrm{mM})$ of $\mathrm{ZP}$ were diluted to $100 \mu \mathrm{M}$ with DMEM and added to the cells in DMEM containing $1 \%$ FCS by bath application for a final dye concentration of $10 \mu \mathrm{M}$. The cells were incubated with the probe for $2 \mathrm{~h}$ at $37^{\circ} \mathrm{C}$ and under $5 \% \mathrm{CO}_{2}$, washed with serum-free DMEM $(2 \times 2$ $\mathrm{mL})$, and bathed in serum-free DMEM $(2 \mathrm{~mL})$ before imaging. Stock solutions of $\mathrm{Zn}(\mathrm{II}) /$ pyrithione (1:2 $\mathrm{Zn}(\mathrm{II}) /$ pyrithione ratio prepared from $\mathrm{ZnCl}_{2}$ and sodium pyrithione, $10 \mathrm{mM}$ ) and $N^{\prime}, N^{\prime}, N$ ", $N$ "-tetrakis(2-picolyl)-ethylenediamine (TPEN, $40 \mathrm{mM}$ ) in DMSO were diluted 10- and 40-fold with DMEM prior to cell treatment.

\section{Hippocampal Slice Preparation}

The whole brains of 90-day-old female Sprague-Dawley rats were removed. The hippocampi were dissected on ice, cut into 200 to $\sim 400 \mu \mathrm{m}$ thick slices and washed twice with Zn(II)-free Kreb's ringer buffer (literature protocol). ${ }^{38}$ The slices were incubated with $10 \mu \mathrm{M}$ dye in $\mathrm{Zn}$ (II)-free Kreb's ringer buffer $\left(T=37^{\circ} \mathrm{C}, 5 \% \mathrm{CO}_{2}\right)$ for 10-20 min, washed thoroughly with the $\mathrm{Zn}$ (II)-free buffer, and transferred to a glass-bottom imaging dish with a minimum volume of buffer for imaging.

\section{Confocal Fluorescence Microscopy}

A Zeiss LSM510 laser scanning microscopy system, based on an Axiovert 200M inverted fluorescence microscope, was used for confocal fluorescence imaging. The microscope was equipped with an argon ion laser $\left(\lambda_{\mathrm{ex}}=488 \mathrm{~nm}\right), 10 \times$ or $63 \times$ objective lens, and a $505 \mathrm{~nm}$ long pass emission filter. During the imaging experiments, the samples were kept on the microscope stage in a CTI-3700 incubator set at $37^{\circ} \mathrm{C}$ under $5 \% \mathrm{CO}_{2}$. Additions of $\mathrm{Zn}(\mathrm{II}) /$ pyrithione and TPEN solutions to the biological samples were performed directly on the microscope stage by bath application. The Metamorph software package was used for quantification.

\section{Results and Discussion}

\section{Syntheses}

Sensors ZP9 and ZP10 were prepared by a convergent route that involves the combination of an asymmetrical aldehyde-functionalized fluorescein and the aniline-based ligand moiety. ${ }^{26}$ Scheme 1 depicts the syntheses of ligand fragments $\mathbf{8}$ and $\mathbf{1 1}$ and the assemblies of sensors ZP9 and ZP10. The pyridyl-amine-pyrrole ligand $\mathbf{4}$ was prepared from 2-(aminomethyl) pyridine and 2-pyrrolecar-boxaldehyde according to a literature procedure. ${ }^{35}$ The $N$-methyl analogue, $\mathbf{5}$, was obtained in an $82 \%$ yield by an analogous route. Combination of secondary amines $\mathbf{4}$ and $\mathbf{5}$ with 2-nitrobenzylbromide and base produced compounds $\mathbf{7}$ and $\mathbf{1 0}$ as yellow solids in high yields following purification by column chromatography. Reduction of the nitro groups in 7 and 10 to amino groups by hydrogenation using $\mathrm{Pd} / \mathrm{C}$ (10\% activated) was efficient and afforded the aniline-derivatized ligand fragments $\mathbf{8}$ and $\mathbf{1 1}$ in 52 and 60\% yields, respectively, following column chromatography.

The final assembly of sensors ZP9 and ZP10 followed previously described methods. ${ }^{26}$ Schiff base condensation of aldehyde $\mathbf{6}$ and the aniline-derivatized ligands in EtOAc yielded intermediates 9 and 12. The reduction of the imines by $\mathrm{NaB}(\mathrm{OAc})_{3} \mathrm{H}$ in 1,2-dichloroethane occurred readily and could be monitored by changes in solution clarity and color. The solutions of the fully reduced species prepared in this investigation were orange-yellow and clear. Sensors ZP9 and ZP10 were purified by preparative TLC on RP silica gel and obtained as orange solids in moderate yields. An anline-derivatized fluorescein, 13, was prepared analogously as shown in Scheme 2. 


\section{Effect of pH on Sensor Emission}

Photoinduced electron transfer (PET) sensors are often proton sensitive. ${ }^{39,40} \mathrm{We}$ therefore investigated the effect of $\mathrm{pH}$ on the emission properties of ZP9 and ZP10; representative titrations are given in Figure 2. The $\mathrm{pH}$ profiles of these probes are essentially identical, as expected given their structural similarity. Both sensors show $\sim 2$-fold fluorescence enhancement as the $\mathrm{pH}$ is lowered from $\sim 12$ to $\sim 6$, and fluorescence quenching occurs in more acidic solutions. These titrations reveal two protonation events that alter sensor emission significantly and are assigned to aniline $\left(\mathrm{p} K_{\mathrm{a} 1}=7.2, \mathrm{ZP} 9 ; 7.0, \mathrm{ZP} 10\right)$ and fluorescein $\left(\mathrm{p} K_{\mathrm{a} 2}=\right.$ 5.0, ZP9; 4.8, ZP10) protonation (Table 4.1). Nitrogen protonation often causes fluorescence enhancement in PET-based sensors, which accounts for $\mathrm{p} K_{\mathrm{a} 1}$. Fluorescein itself is $\mathrm{pH}$ sensitive, 41 and its emission is quenched at low $\mathrm{pH}$, which forms the basis for the assignment of $\mathrm{p} K_{\mathrm{a} 2}$. To understand the latter transition further, we employed optical absorption spectroscopy, and representative spectra for ZP9 are given in Figure S1 (Supporting Information). The optical absorption spectra of fluorescein in its various protonation states are distinctive. The spectra of ZP9 at a pH of $>7$ are indicative of the fluorescein dianion, whereas those at lower $\mathrm{pH}$, with peaks at 484 and $459 \mathrm{~nm}$ of similar and significantly lower molar absorptivity, signal phenol protonation and formation of the fluorescein monoanion. ${ }^{41}$ Based on these observations, we propose the protonation equilibria for ZP9 and ZP10 shown in Scheme 3 where "observed" indicates the transitions detected by fluorimetric titrations. On the basis of literature studies of $2^{\prime}, 7^{\prime}$-dichlorofluorescein, ${ }^{42}$ we expect protonation of the keto group to occur at a $\mathrm{pH}$ of $<1$.

The preceeding two-component $\mathrm{p} K_{\mathrm{a}}$ analysis suggests that protonation of the tertiary amines in $\mathrm{ZP9}$ and $\mathrm{ZP10}$ has little influence on fluorophore emission. Investigation of the $\mathrm{pH}-$ dependent emission of $\mathbf{1 3}$ generally supports this notion (Figure 2, Scheme S1). The emission of $\mathbf{1 3}$ shows essentially no change as the $\mathrm{pH}$ is lowered from $\sim 12$ to $\sim 7.5$. A $\sim 2$-fold fluorescence increase occurs between $\mathrm{pH} \sim 7.5$ and $\sim 5.4$, which returns a $K_{\mathrm{a} 1}$ value of 6.1 assigned to aniline nitrogen protonation. A further decrease of the $\mathrm{pH}$ causes quenching, with a $K_{\mathrm{a} 2}$ of 4.7. Optical absorption spectroscopy reveals that phenol protonation is responsible for this transition (Figure S1). The $\mathrm{pH}$-dependent fluorescent profiles of both ZP probes and $\mathbf{1 3}$ are therefore similar in the following ways: (i) the maximum emission is quenched by $40-50 \%$ at $\mathrm{pH} 12$;

(ii) this weak background emission is approximately doubled as the $\mathrm{pH}$ is lowered to $\sim 6$, and (iii) further acidification causes the emission to decrease substantially and with comparable $\mathrm{p} K_{\mathrm{a}}$ values. Some differences in the $\mathrm{p} K_{\mathrm{a} 1}$ transition for $\mathbf{1 3}$ and $\mathrm{ZP} 9$ and ZP10 are also worth noting. In contrast to the stable emission from 13 over the $\mathrm{pH}$ range from $\sim 12$ to $\sim 7.5, \mathrm{ZP} 9$ and ZP10 both show an $\sim 1.5$-fold increase in integrated emission, which may suggest that tertiary amine protonation has some contribution to the observed fluorescence enhancement in this $\mathrm{pH}$ regime. Given that a two-parameter model returns an excellent fit $(r=0.997$ for both ZP9 and ZP10), we opted not to incorporate a third variable, but we acknowledge that some contribution from tertiary amine protonation may influence emission in this $\mathrm{pH}$ range. Nevertheless, any such effect is small because these compounds, and other aniline-based sensors with ${ }^{21}$ and without $^{33}$ tertiary-amine-based ligand appendages, have similar $\Phi_{\text {free }}$ values at neutral $\mathrm{pH}$ (vide infra).

\section{Spectroscopic Properties of ZP9 and ZP10}

Table 1 details the spectroscopic characterization of ZP9 and ZP10, in addition to data for structurally related Zn(II) sensors. ZP9 and ZP10 differ from one another only in the substitution on the pyrrole nitrogen atom, and we anticipated that they would exhibit comparable features. The data in Table 1 generally support this expectation. ZP9 and ZP10 both have fluorescein-dominated emission spectra with $\lambda_{\max } \approx 520 \mathrm{~nm}$ and $\Phi_{\text {free }}<0.1(50 \mathrm{mM}$ PIPES, $100 \mathrm{mM} \mathrm{KCl}, \mathrm{pH}$ 7). These quantum efficiencies are in the range of most asymmetrical fluorescein-based metal ion sensors that employ aniline-based chelates designed by our group. This comparison suggests that the aniline-based ZP platform is relatively insensitive to 
variations in the tertiary amine fragment. Photophysical characterization of compound $\mathbf{1 3}$, which has $\Phi_{\text {free }}=0.06(50 \mathrm{mM}$ PIPES, $100 \mathrm{mM} \mathrm{KCl}, \mathrm{pH}$ 7), further substantiates this claim and reveals that fluorescence quenching observed in aniline-derivatized fluoresceins can be attributed to the aniline moiety with little, if any, contribution from the tertiary amine fragment. Such insensitivity to ligand variations is an advantage toward achieving a sensor series with similar photophysical properties and varied affinity or Zn(II) selectivity.

The fluorescence responses of ZP9 and ZP10 to Zn(II) are shown in Figure 3. Solutions of ZP9 and ZP10 exhibit immediate fluorescence turn-on following $\mathrm{Zn}$ (II) addition. Both sensors give full emission enhancement in the presence of $>10$ equiv of $\mathrm{Zn}$ (II) with $\Phi_{\mathrm{Zn}}>0.30(50 \mathrm{mM}$ PIPES, $100 \mathrm{mM} \mathrm{KCl}, \mathrm{pH} 7$ ) and with $\sim 12$ - and $\sim$ 7-fold turn-on for ZP9 and ZP10, respectively. Blue shifts in both absorption and emission maxima occur as a result of $\mathrm{Zn}$ (II) binding, indicative of $\mathrm{Zn}(\mathrm{II})$ coordination to the phenol group. The absorption properties of ZP9 and ZP10, which are dominated by the fluorescein chromophore, are also listed in Table 1 and follow expected trends. Figure S2 includes representative absorption spectra for the free and $\mathrm{Zn}$ (II)-bound sensors and the corresponding difference spectra, which show absorption decreases at $~ 511,297$, and $249 \mathrm{~nm}$ and increases at 461 and $490 \mathrm{~nm}$. These features and the hypsochromic shift of $A_{\text {max }}$ with $\mathrm{Zn}$ (II) coordination are consistent with those of previously reported ZP sensors. $20,22,26$

\section{Thermodynamics and Kinetics of Zn(II) Binding to ZP9 and ZP10}

Table 2 summarizes the thermodynamic and kinetic parameters for Zn(II) coordination to ZP9 and ZP10. Both sensors were designed to bind Zn(II) with 1:1 stoichiometry, and Job plots are given in Figure S3. Fluorimeteric titrations reveal that ZP9 has an apparent zinc complex $K_{\mathrm{d}}$ value of $0.69 \pm 0.04 \mu \mathrm{M}$ (Fig. S4). This value is approximately 3 orders of magnitude higher than those for the parent ZP sensors $\left(K_{\mathrm{d} 1}<1 \mathrm{nM}\right),{ }^{21} \sim 1.5$ orders of magnitude higher than that of Fluo-3N $\left(K_{\mathrm{d}}=15 \mathrm{nM}\right), 43$ a commercially available $\mathrm{Zn}(\mathrm{II})$ sensor that employs a modified BAPTA chelate, and similar to the $K_{\mathrm{d}}$ values of $\mathrm{Me}_{4} \mathrm{ZP} 1\left(K_{\mathrm{d} 1}=0.63 \mu \mathrm{M}\right)^{31}$ and ZnAF-3 $\left(K_{\mathrm{d}}=0.79 \mu \mathrm{M}\right) .{ }^{6}$ Substitution of the pyrrole with $N$-methylpyrrole further increases the $K_{\mathrm{d}}$ value to $1.9 \pm 0.2 \mu \mathrm{M}$ (Figure S3). Given the spectroscopic similarities between ZP4, ZP9, and $\mathrm{ZP10}$, we anticipate that their parallel use for biological imaging will be of benefit and will allow for bracketing relative $\mathrm{Zn}$ (II) concentrations in the sub-nanomolar to low-micromolar range, the latter being midrange.

Stopped-flow kinetics investigations were conducted to determine the association rates, measured by fluorescence turn-on, of Zn(II) binding to ZP9 and ZP10. Representative plots of $k_{\text {obs }}$ versus $\mathrm{Zn}$ (II) concentration $\left(T=4.3^{\circ} \mathrm{C}\right)$ yield second-order rate constants of $3.00 \pm 0.09$ $\times 10^{5}$ (ZP9) and $2.04 \pm 0.04 \times 10^{5} \mathrm{M}^{-1} \mathrm{~s}^{-1}$ (ZP10) (Table 2, Figure S5). The smaller $k_{\text {on }}$ value for ZP10 may result from a steric effect caused by the $N$-methyl group on the pyrrole moiety. Temperature-dependent studies reveal $k_{\text {on }}$ values of $>2 \times 10^{6} \mathrm{M}^{-1} \mathrm{~s}^{-1}$ at $25^{\circ} \mathrm{C}$ (Table 2). These association rates indicate rapid $\mathrm{Zn}$ (II) complexation and are of similar magnitude to the $k_{\text {on }}$ values for DPA-based ZP $\left(3.3-5.2 \times 10^{6} \mathrm{M}^{-1} \mathrm{~s}^{-1}, T=25^{\circ} \mathrm{C}\right)^{33}$ and ZnAF family members $\left(1.3-3.1 \times 10^{6} \mathrm{M}^{-1} \mathrm{~s}^{-1}, T=25^{\circ} \mathrm{C}\right) .{ }^{12}$ The calculated $k_{\text {off }}$ values for ZP9 and ZP10 are $\sim 1.5$ and $\sim 4.0 \mathrm{~s}^{-1}$, respectively, at $T=25^{\circ} \mathrm{C}$, which indicates significantly more rapid $\mathrm{Zn}$ (II) dissociation as compared to ZP sensors with the DPA chelate $\left(2.3-3.4 \times 10^{-3} \mathrm{~s}^{-1}, T=25^{\circ} \mathrm{C}\right)$. 33 This feature may be important for imaging $\mathrm{Zn}$ (II) flux during signaling events.

Variable-temperature experiments were performed over the range from $\sim 4$ to $\sim 40{ }^{\circ} \mathrm{C}$, and representative Eyring plots are given in Figures S6 and S7. The values for the activation enthalpies, $\Delta H^{\ddagger}$, are $14.4 \pm 0.1$ (ZP9) and $14.9 \pm 0.6$ (ZP10) kcal mol${ }^{-1}$ and indicate a low activation barrier and fast association. The activation enthalpies, $\Delta S^{\ddagger}$, are $18.3 \pm 0.9$ (ZP9) and $20.3 \pm 2.0(\mathrm{ZP} 10) \mathrm{cal} \mathrm{mol}^{-1} \mathrm{~K}^{-1}$. Positive values were previously observed ${ }^{33}$ for selected $\mathrm{ZP}$ 
and QZ sensors (Table 2) and may reflect the dissociation of water molecules or buffer components from the $\mathrm{Zn}$ (II) coordination sphere in the rate-determining step.

\section{Selectivity of ZP9 and ZP10 for Zn(II)}

Figure 4 details the selectivity of ZP9 for Zn(II), and the data for ZP10 are comparable. Because they provide nitrogen-rich coordination spheres, ZP9 and ZP10 are selective for $\mathrm{Zn}$ (II) over milli-molar concentrations of $\mathrm{K}(\mathrm{I}), \mathrm{Na}(\mathrm{I}), \mathrm{Ca}(\mathrm{II})$, and $\mathrm{Mg}(\mathrm{II})$. Of the divalent first-row transition metal ions considered, these sensors are selective for $\mathrm{Zn}$ (II) over both $\mathrm{Mn}$ (II) and $\mathrm{Fe}$ (II). The selectivity for $\mathrm{Zn}$ (II) over Fe(II) is a significant advantage relative to ZP1-8 and similar to the behavior observed for ZS4. Substitution of one pyridyl group from the DPA unit with another moiety routinely conveys selectivity for $\mathrm{Zn}$ (II) over Fe(II). The data presented in Figure 4 also reveal that the pyrrole-containing sensors are selective for $\mathrm{Zn}$ (II) over its Group 12 congeners $\mathrm{Cd}$ (II) and $\mathrm{Hg}$ (II). This feature is an improvement over thioether-containing ZS sensors, which preferentially bind $\mathrm{Hg}$ (II) over $\mathrm{Zn}$ (II), and can be rationalized with the hardsoft acid-base (HSAB) principle, whereby sensors with nitrogen-rich chelates preferentially coordinate to $\mathrm{Zn}(\mathrm{II})$, whereas those with a thioether group bind $\mathrm{Hg}$ (II) more tightly.

\section{Biological Imaging Applications}

Given the fluorescence properties and Zn(II) affinities of ZP9 and ZP10, we initiated studies of their distribution and $\mathrm{Zn}(\mathrm{II})$ response in biological samples. Our initial expectations were based on previous biological imaging conducted with ZP4. Early studies with this probe showed that it selectively labels damaged neurons in brain tissue, ${ }^{21,34}$ and subsequent work in our laboratory with a basic tissue culture room microscope suggested that ZP4-6 do not readily enter cultured cells. ${ }^{26}$ From these observations, ZP4 and its derivatives were assumed to be cell impermeable and useful for extracellular imaging. Given the structural similarities between ZP4 and the pyrrole derivatives described in this work, we reasoned that ZP9 and ZP10 would similarly be unable to penetrate the cell membrane without modification. We therefore prepared ZP9- Piv by reaction of ZP9 with excess pivalic anhydride in the presence of base (Scheme S2). This approach, which affords the lipophilic lactone isomer of fluorescein, is commonly used for delivering an otherwise impermeable probe into cells.

Preliminary control studies suggested otherwise. Laser scanning confocal microscopy revealed that HEK cells treated with either ZP9 or ZP9-Piv exhibited intracellular staining. Further work definitively showed that ZP9 can enter cells and respond to exogenously added Zn(II), delivered by addition of the cell-permeable ionophore pyrithione. Representative images are given in Figure 5. Quantification of the response indicates a $\sim$-fold intracellular fluorescence enhancement following a $2 \mathrm{~h}$ dye incubation period and treatment with 5 equiv of $\mathrm{Zn}(\mathrm{II}) /$ pyrithione. Addition of the cell-permeable chelator TPEN reversed the fluorescence increase to within $20 \%$ of the baseline value, which confirms that the fluorescence increase results from $\mathrm{Zn}$ (II) coordination and not some other phenomena, such as a proton flux or sensor photoactivation.

On the basis of our knowledge of ZP4, the behavior of ZP9 was a surprise. We concluded that relative incubation time is a key factor when defining the permeability of a probe and that an "appropriate" incubation time will also depend on the type of cell or tissue under study. An incubation time of only $\sim 1$ min was employed during the first experiments conducted with ZP4 in samples of brain tissue, ${ }^{21}$ which was presumably too short for the probe to enter healthy cells. We therefore investigated ZP4 staining of cultured HEK cells in detail and observed a distribution and response comparable to that of $\mathrm{ZP9} .{ }^{44}$ These studies point to the need for caution when designating a given sensor as intra- or extracellular and the necessity for rigorous control experiments. 
Knowing that ZP4 and ZP9 can penetrate cell membranes and respond to $\mathrm{Zn}$ (II) in vivo, we sought to employ these probes to detect endogenous $\mathrm{Zn}$ (II) pools. We therefore treated acute hippocampal slices from adult rat brain with $10 \mu \mathrm{M} \mathrm{ZP} 4$ or ZP9 for $10-20 \min \left(T=37^{\circ} \mathrm{C}, 5 \%\right.$ $\mathrm{CO}_{2}$ ). Figure 6 shows the confocal images obtained for a representative slice treated with ZP9 and subsequently with $50 \mu \mathrm{M}$ TPEN. The dentate gyrus region, which contains gluta-matergic neurons rich in vesicular zinc, is illuminated, and the signal is reversed with TPEN addition, which indicates that ZP9 $\left(K_{\mathrm{d}}<1 \mu \mathrm{M}\right)$ can detect endogenous $\mathrm{Zn}$ (II) in this region. ZP4 $\left(K_{\mathrm{d}}<\right.$ $1 \mathrm{nM}$ ) also stains the $\mathrm{Zn}$ (II)-rich regions of the mammalian hippocampus (Figure 7). We note that optical $z$-sectioning of a ZP treated hippocampal slice confirms that the sensor has indeed penetrated the tissue (Figure S8). The ZP4 staining pattern differs significantly from those first obtained with a $\sim 1$ min incubation (room temperature, $3 \mathrm{~h}$ after slicing), ${ }^{21}$ which reflects one or more variations in the slice preparation and staining protocols. During the course of our work, ZP4 permeability was reported in hippocampal slices ( $0.5-3 \mathrm{~h}$ incubation) in a study of synaptic activation. 45

\section{Summary and Perspectives}

Investigations of ZP9 and ZP10 reveal several important facets of zinc sensor design and biological application. Incorporation of pyrrole groups affords a new strategy for increasing the $\mathrm{Zn}$ (II) dissociation constant and improving $\mathrm{Zn}$ (II) selectivity relative to sensors that use the DPA chelate. Through consideration of compound 13, we determined that the fluorescence quenching of aniline-based sensors is primarily, if not completely, caused by the aniline moiety itself. This observation is an important one and suggests that systematic modification of this sensor platform, via changes in the groups of the tertiary amine unit, will afford a series of $\mathrm{Zn}$ (II) sensors with comparable optical properties that span a range of dissociation constants. Along these lines, we anticipate that parallel use of ZP4 and ZP9 for biological imaging will be of benefit and will allow for bracketing relative $\mathrm{Zn}$ (II) concentrations in the nanomolar range. Finally, confocal imaging studies with ZP9 were particularly revealing and showed that aniline-based probes are cell permeable. As a result of this observation and subsequent studies, we revise our original claim that $\mathrm{ZP} 4^{21}$ and its derivatives are exclusively extracellular $\mathrm{Zn}$ (II) sensors.

\section{Acknowledgements}

This work was supported by Grant GM65519 from the National Institute of General Medical Sciences. Spectroscopic instrumentation at the MIT DCIF is maintained by funding from NIH Grant 1S10RR13886-01 and NSF Grants CHE-9808061, CH3-9808063, and DB19729592. M.S. is an Investigator of the Howard Hughes Medical Institute. M.E.R. thanks the Undergraduate Research Opportunities Program at MIT for partial financial support. E.M.N. thanks the Whitaker Health Science Fund for a graduate fellowship, Strem Chemicals, Inc. for a gift of ZP4, and Mr. J. W. Ryu and Mr. D. P. Seeburg for assistance with the ZP4 slice experiment.

\section{References}

1. Chang, CJ.; Lippard, SJ. Neurodegenerative Diseases and Metal Ions; Metal Ions in Life Sciences. Sigel, A.; Sigel, H.; Sigel, RKO., editors. 1. Wiley: New York; 2006. p. 321-370.

2. Fierke CA, Thompson RB. BioMetals 2001;14:205-222. [PubMed: 11831457]

3. Gee KR, Zhou ZL, Ton-That D, Sensi SL, Weiss JH. Cell Calcium 2002;31:245-251. [PubMed: 12098227]

4. Shults MD, Pearce DA, Imperiali B. J Am Chem Soc 2003;125:10591-10597. [PubMed: 12940742]

5. Henary MM, Wu Y, Fahrni CJ. Chem Eur J 2004;10:3015-3025.

6. Komatsu K, Kikuchi K, Kojima H, Urano Y, Nagano T. J Am Chem Soc 2005;127:10197-10204. [PubMed: 16028930]

7. Frederickson CJ. Int Rev Neurobiol 1989;31:145-238. [PubMed: 2689380]

8. Frederickson CJ, Koh JH, Bush AI. Nat Neurosci 2005;6:449-462. 
9. Bozym RA, Thompson RB, Stoddard AK, Fierke CA. ACS Chem Biol 2006;1:103-111. [PubMed: 17163650]

10. de Silva SA, Zavaleta A, Baron DE, Allam O, Isidor EV, Kashimura N, Percarpio JM. Tetrahedron Lett 1997;38:2237-2240.

11. Hirano T, Kikuchi K, Urano Y, Higuchi T, Nagano T. J AmChem Soc 2000;122:12399-12400.

12. Hirano T, Kikuchi K, Urano Y, Nagano T. J Am Chem Soc 2002;124:6555-6562. [PubMed: 12047174]

13. Maruyama S, Kikuchi K, Hirano T, Urano Y, Nagano T. J Am Chem Soc 2002;124:10650-10651. [PubMed: 12207508]

14. Kiyose K, Kojima H, Urano Y, Nagano T. J Am Chem Soc 2006;128:6548-6549. [PubMed: 16704241]

15. Kim TW, Park JH, Hong JI. J Chem Soc, Perkin Trans 2 2002:923-927.

16. Lim NC, Brückner C. Chem Commun 2004:1094-1095.

17. Lim NC, Schuster JV, Porto MC, Tanudra MA, Yao L, Freake HC, Brückner C. Inorg Chem 2005;44:2018-2030. [PubMed: 15762729]

18. Wu Y, Peng X, Guo B, Fan J, Zhang Z, Wang J, Cui A, Gao Y. Org Biomol Chem 2005;3:13871392. [PubMed: 15827633]

19. Walkup GK, Burdette SC, Lippard SJ, Tsien RY. J Am Chem Soc 2000;122:5644-5645.

20. Burdette SC, Walkup GK, Spingler B, Tsien RY, Lippard SJ. J Am Chem Soc 2001;123:7831-7841. [PubMed: 11493056]

21. Burdette SC, Frederickson CJ, Bu W, Lippard SJ. J Am Chem Soc 2003;125:1778-1787. [PubMed: 12580603]

22. Chang CJ, Nolan EM, Jaworski J, Burdette SC, Sheng M, Lippard SJ. Chem Biol 2004;11:203-210. [PubMed: 15123282]

23. Woodroofe CC, Masalha R, Barnes KR, Frederickson CJ, Lippard SJ. Chem Biol 2004;11:1659_ 1666. [PubMed: 15610850]

24. Woodroofe CC, Lippard SJ. J Am Chem Soc 2003;125:11458-11459. [PubMed: 13129323]

25. Woodroofe CC, Won AC, Lippard SJ. Inorg Chem 2005;44:3112-3120. [PubMed: 15847416]

26. Nolan EM, Burdette SC, Harvey JH, Hilderbrand SA, Lippard SJ. Inorg Chem 2004;43:2624-2635. [PubMed: 15074981]

27. Chang CJ, Nolan EM, Jaworski J, Okamoto KI, Hayashi Y, Sheng M, Lippard SJ. Inorg Chem 2004;43:6774-6779. [PubMed: 15476377]

28. Chang CJ, Jaworski J, Nolan EM, Sheng M, Lippard SJ. Proc Natl Acad Sci USA 2004;101:1129_ 1134. [PubMed: 14734801]

29. Anderegg G, Hubmann E, Podder NG, Wenk F. Helv Chim Acta 1977;60:123-140.

30. Gruenwedel DW. Inorg Chem 1968;7:495-501.

31. Goldsmith CR, Lippard SJ. Inorg Chem 2006;45:555-561. [PubMed: 16411690]

32. Nolan EM, Lippard SJ. Inorg Chem 2004;43:8310-8317. [PubMed: 15606177]

33. Nolan EM, Jaworski J, Okamoto KI, Hayashi Y, Sheng M, Lippard SJ. J Am Chem Soc 2005;127:16812-16823. [PubMed: 16316228]

34. Frederickson CJ, Burdette SC, Frederickson CJ, Sensi SL, Weiss JH, Yin HZ, Balaji RV, TruongTran AQ, Bedell E, Prough DS, Lippard SJ. J Neurosci Methods 2004;139:79-89. [PubMed: 15351524]

35. de Bruin B, Kicken RJNAM, Suos NFA, Donners MPJ, den Reijer CJ, Sandee AJ, de Gelder R, Smits JMM, Gal AW, Spek AL. Eur J Inorg Chem 1999:1581-1592.

36. Brannon JH, Madge D. J Phys Chem 1978;82:705-709.

37. Lim MH, Xu D, Lippard SJ. Nat Chem Biol 2006;2:375-380. [PubMed: 16732295]

38. Qian WJ, Gee KR, Kennedy RT. Anal Chem 2003;75:3468-3475. [PubMed: 14570199]

39. de Silva AP, Gunaratne HQN, Gunnlaugsson T, Huxley AJM, McCoy CP, Rademacher JT, Rice TE. Chem Rev 1997;97:1515-1566. [PubMed: 11851458]

40. Callan JF, de Silva AP, Magri DC. Tetrahedron 2005;61:8551-8588.

41. Sjöback R, Nygren J, Kubista M. Spectrochim Acta, Part A 1995;51:L7-L21. 
42. Leonhardt H, Gordon L, Livingston R. J Phys Chem 1971;75:245-249.

43. Gee KR, Zhou ZL, Qian WJ, Kennedy R. J Am Chem Soc 2002;124:776-778. [PubMed: 11817952]

44. Nolan, EM.; Frederickson, CJ.; Lippard, SJ. Unpublished results

45. Kay AR, Tóth K. J Neurophysiol 2006;95:1949-1956. [PubMed: 16319204] 


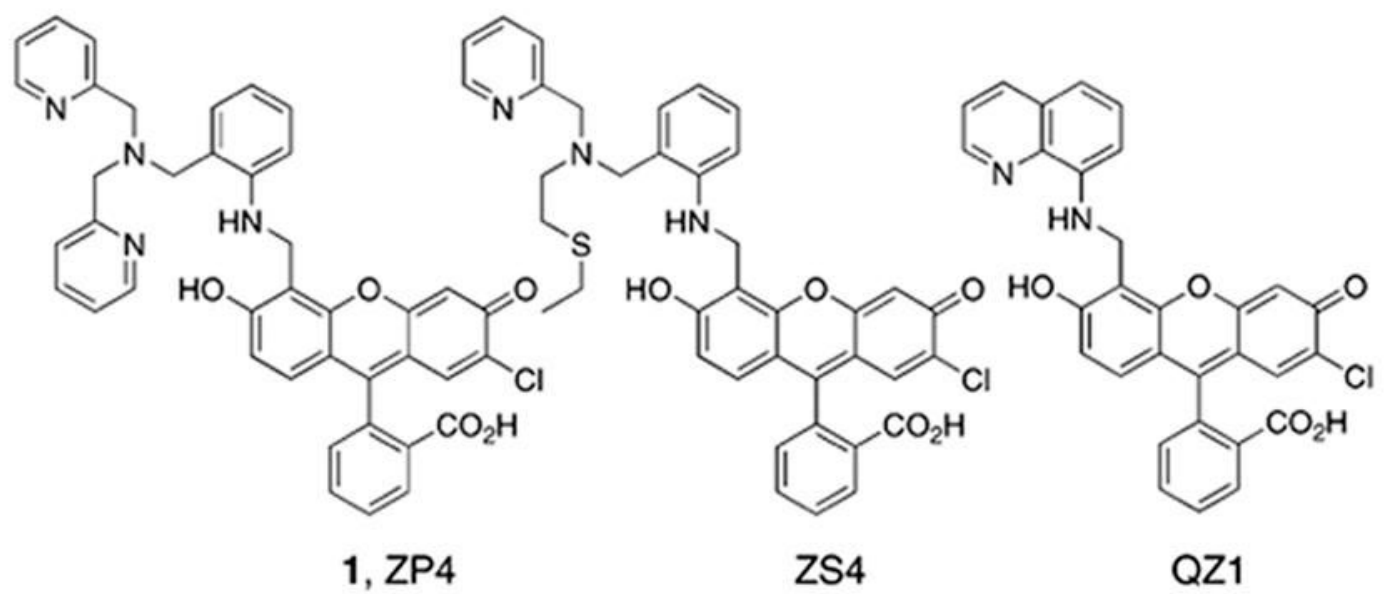

Figure 1.

Examples of asymmetrical fluorescein-based Zn(II) sensors of the Zinpyr, Zinspy, and QZ families. 


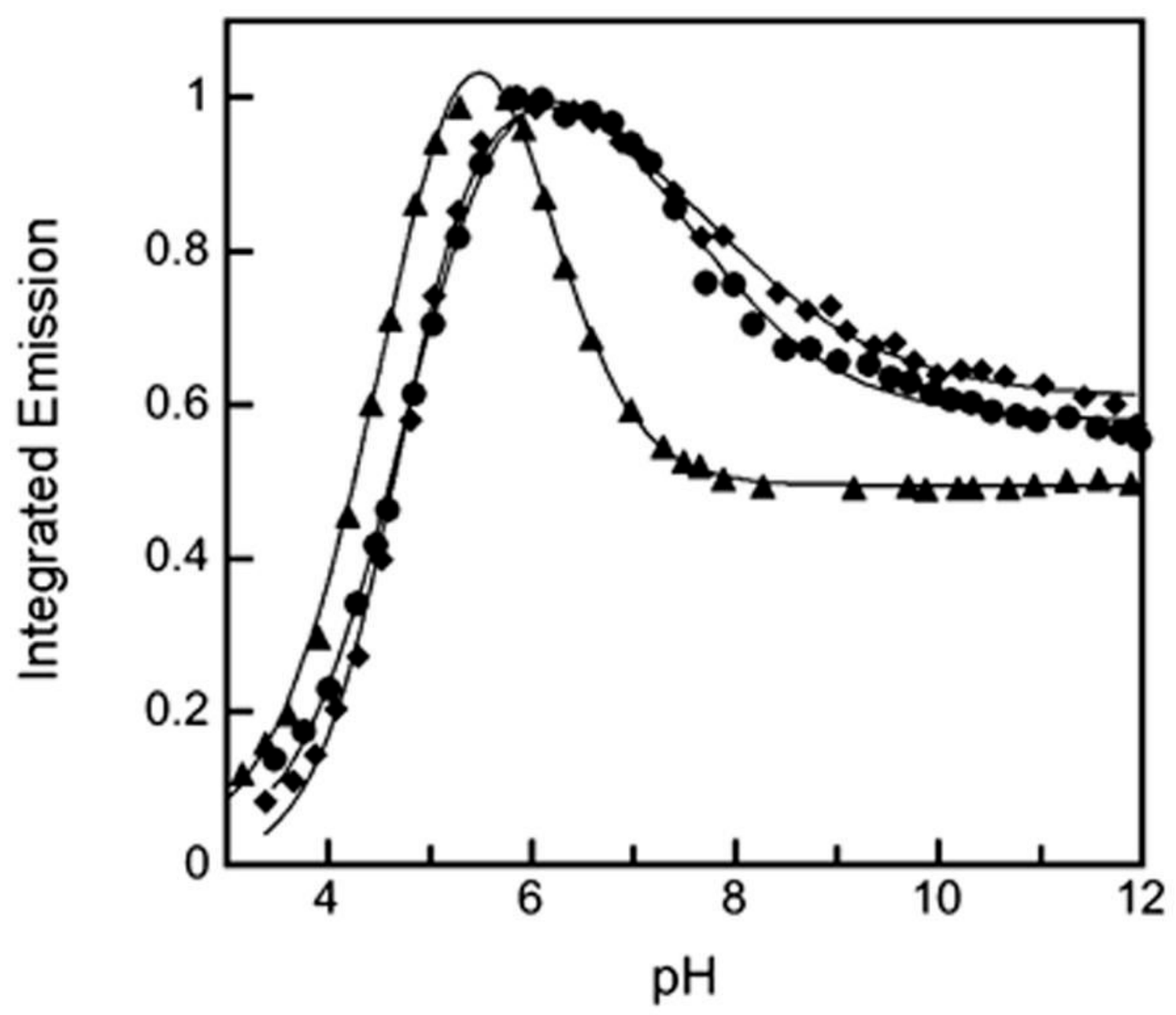

Figure 2.

Effect of pH on the emission of ZP9 $(\bullet)$, ZP10 (४), and $13(\bullet)$. Solutions of $1 \mu \mathrm{M}$ dye were prepared in $10 \mathrm{mM} \mathrm{KOH}, 100 \mathrm{mM} \mathrm{KCl}(\mathrm{pH} \sim 12)$. The $\mathrm{pH}$ was lowered in increments of $\sim 0.25$ by the addition of aqueous $\mathrm{HCl}$, and the fluorescence spectrum was recorded at each point. The data were integrated, normalized, and plotted against $\mathrm{pH}$. Excitation was provided at 495 (ZP9, ZP10) or $500(\mathbf{1 3}) \mathrm{nm}$ and $T=25^{\circ} \mathrm{C}$. 

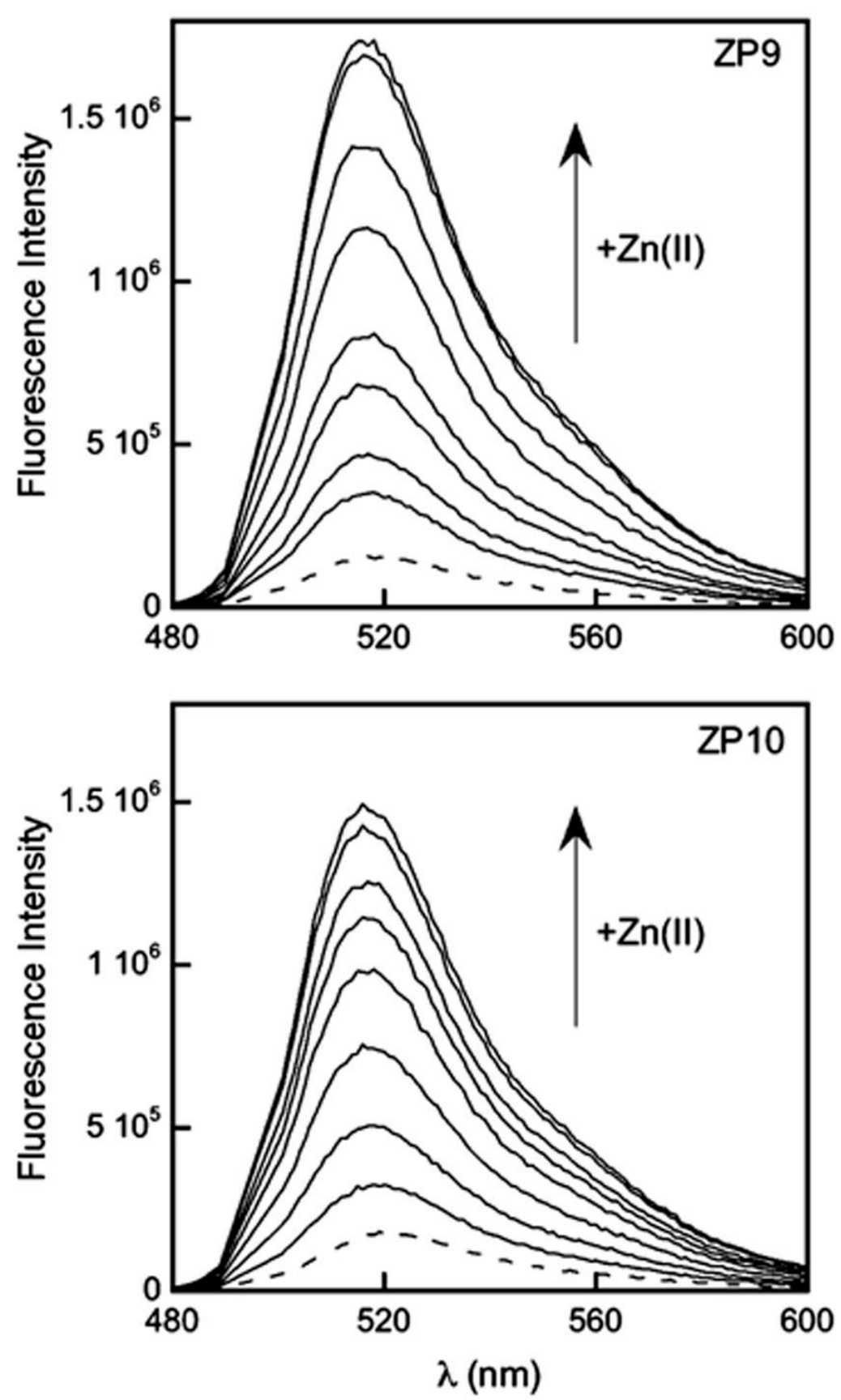

Figure 3.

Fluorescence response of ZP9 and ZP10 to Zn(II) at pH 7 (50 mM PIPES, $100 \mathrm{mM} \mathrm{KCl).} \mathrm{(top)}$ The dashed line indicates the emission from a $1 \mu \mathrm{M}$ solution of ZP9. The solid lines represent the fluorescence enhancement that occurs in the presence of $0.17,0.33,0.66,1,2,4,7$, and 30 $\mu \mathrm{M} \mathrm{Zn}$ (II). (bottom) The dashed line indicates the emission from a $1 \mu \mathrm{M}$ solution of ZP10. The solid lines represent the fluorescence enhancement that occurs in the presence of $0.33,1$, 2, 4, 6, 8, 20, and $30 \mu \mathrm{M} \mathrm{Zn}$ (II). Excitation was provided at $497 \mathrm{~nm}$ and $T=25^{\circ} \mathrm{C}$. 

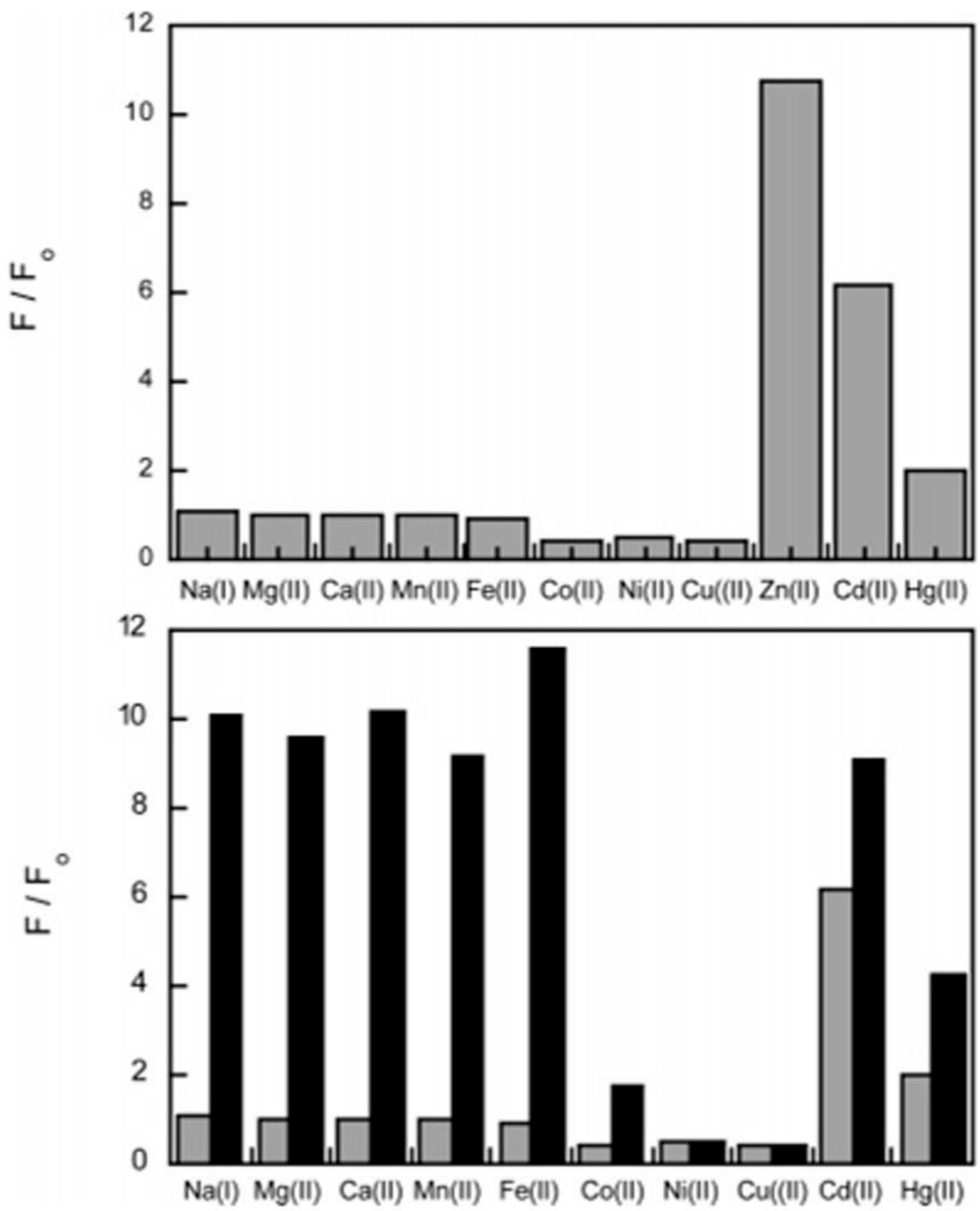

Figure 4.

Selectivity of ZP9 for $\mathrm{Zn}$ (II) in the presence of other cations. (top) Fluorescence response of $1 \mu \mathrm{M}$ ZP9 to 50 equiv of the cation of interest. The response $(F)$ is normalized with respect to the emission of the free dye $\left(F_{\mathrm{o}}\right)$. (bottom) The fluorescence response of the solutions depicted in the top plot to $\mathrm{Zn}(\mathrm{II})$. The gray bars correspond to the bars in the top plot. The black bars indicate the normalized fluorescence response of the solutions immediately after introduction of $50 \mu \mathrm{M} \mathrm{Zn}$ (II). Excitation was provided at $495 \mathrm{~nm}$. The responses of ZP9 and ZP10 to Zn (II) are also unaffected by millimolar concentrations of $\mathrm{Na}(\mathrm{I}), \mathrm{K}(\mathrm{I}), \mathrm{Mg}(\mathrm{II})$, and $\mathrm{Ca}(\mathrm{II})$. 

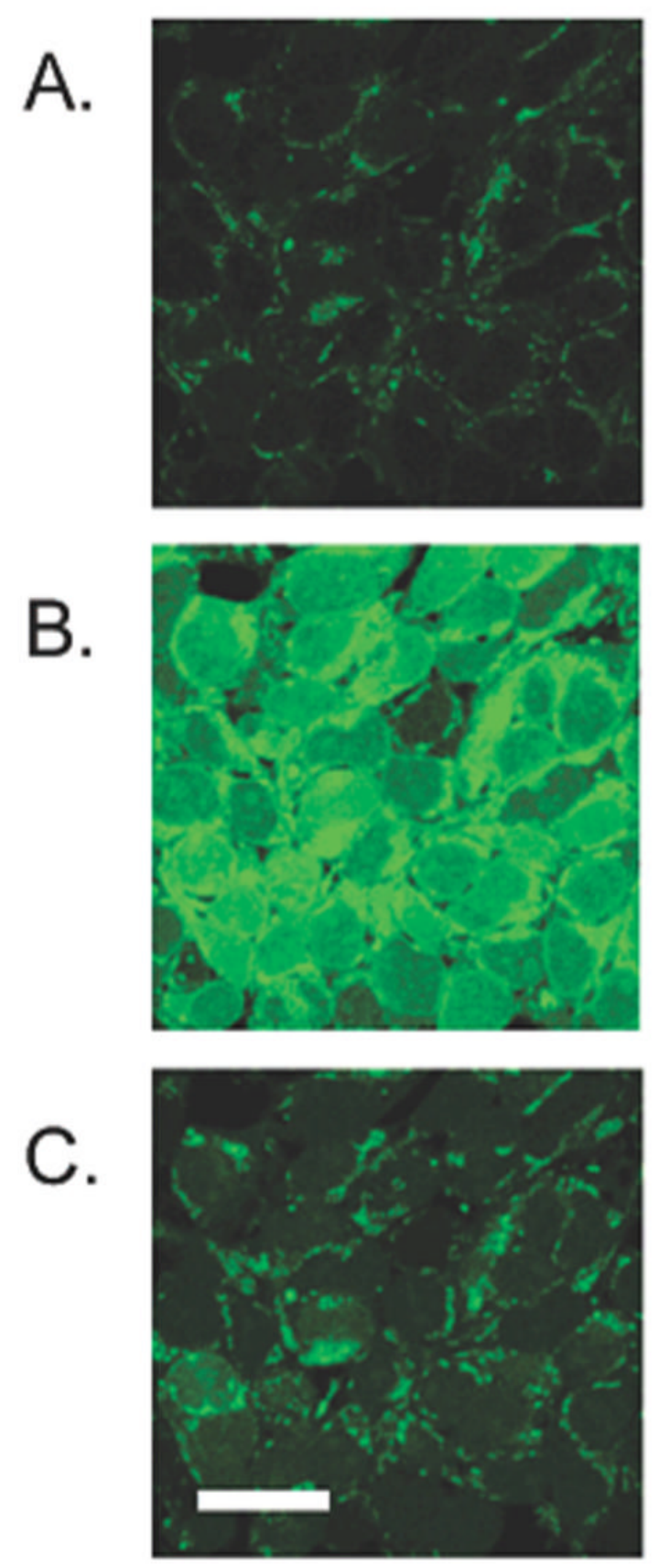
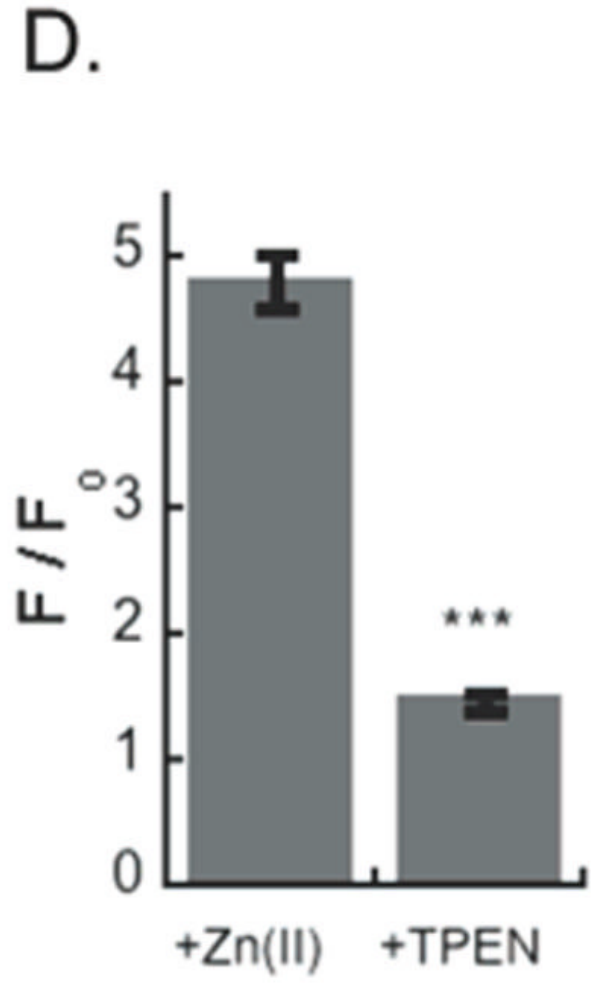

Figure 5.

(A) Confocal fluorescence imaging of HEK293-T cells treated with ZP9 $(10 \mu \mathrm{M}, 2 \mathrm{~h}, T=37$ ${ }^{\circ} \mathrm{C}, 5 \% \mathrm{CO}_{2}$ ). (B) Fluorescence images obtained following treatment with $1: 2 \mathrm{ZnCl}_{2} /$ pyrithione $\left(50 \mu \mathrm{M}, 10 \mathrm{~min}, T=37^{\circ} \mathrm{C}, 5 \% \mathrm{CO}_{2}\right)$. (C) Fluorescence decrease observed following incubation with TPEN $\left(50 \mu \mathrm{M}, 10 \mathrm{~min}, T=37^{\circ} \mathrm{C}, 5 \% \mathrm{CO}_{2}\right)$. The scale bar indicates $25 \mu \mathrm{m}$. (D) Quantification of the fluorescence rise and fall resulting from $\mathrm{Zn}$ (II) and TPEN treatments, respectively. The data $(F)$ are normalized with respect to cells treated only with ZP9 $\left(F_{\mathrm{o}}\right)$. A total of 32 cells were quantified and $* * *$ indicates $p<0.001$ (Mann-Whitney test). The error bars represent the standard error of the mean. 

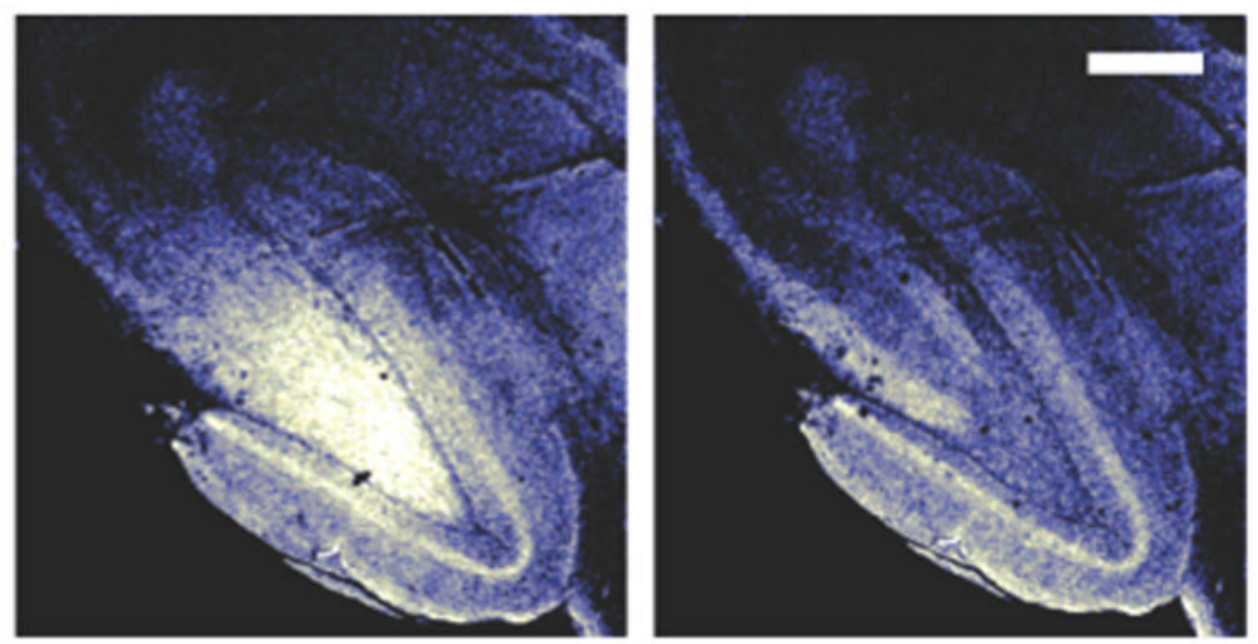

\section{ZP9 TPEN}

Figure 6.

Confocal fluorescence images of an acute hippocampal slice from an adult female SpragueDawley rat. (left) The hippocampal slice was incubated with $10 \mu \mathrm{M}$ ZP9 for $10 \min \left(T=37^{\circ}\right.$ $\mathrm{C}, 5 \% \mathrm{CO}_{2}$ ) in $\mathrm{Zn}$ (II)-free Kreb's ringer buffer and washed thoroughly before imaging. Bright fluorescence is observed in the dentate gyrus region. (right) A fluroescence decrease is observed in the dentate gyrus following the addition of $50 \mu \mathrm{M} \operatorname{TPEN}\left(5 \mathrm{~min}, T=37^{\circ} \mathrm{C}, 5 \%\right.$ $\mathrm{CO}_{2}$ ). The scale bar indicates $0.5 \mathrm{~mm}$. 

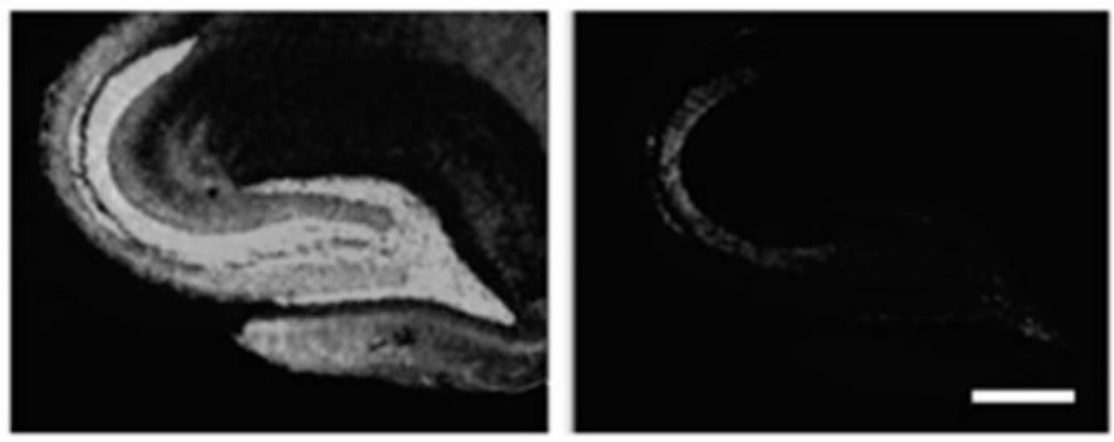

\section{ZP4 TPEN}

Figure 7.

Confocal fluorescence images of an acute hippocampal slice from an adult female SpragueDawley rat. (left) The hippocampal slice was incubated with $10 \mu \mathrm{M} \mathrm{ZP4}$ for $20 \min \left(T=37^{\circ}\right.$ $\mathrm{C}, 5 \% \mathrm{CO}_{2}$ ) in $\mathrm{Zn}(\mathrm{II})$-free Kreb's ringer buffer and washed thoroughly before imaging. Bright fluorescence is observed in the dentate gyrus and CA3 regions. (right) A fluroescence decrease is observed in the dentate gyrus following the addition of $50 \mu \mathrm{M}$ TPEN $\left(20 \mathrm{~min}, T=37^{\circ} \mathrm{C}\right.$, $5 \% \mathrm{CO}_{2}$ ). The scale bar indicates $0.5 \mathrm{~mm}$. 


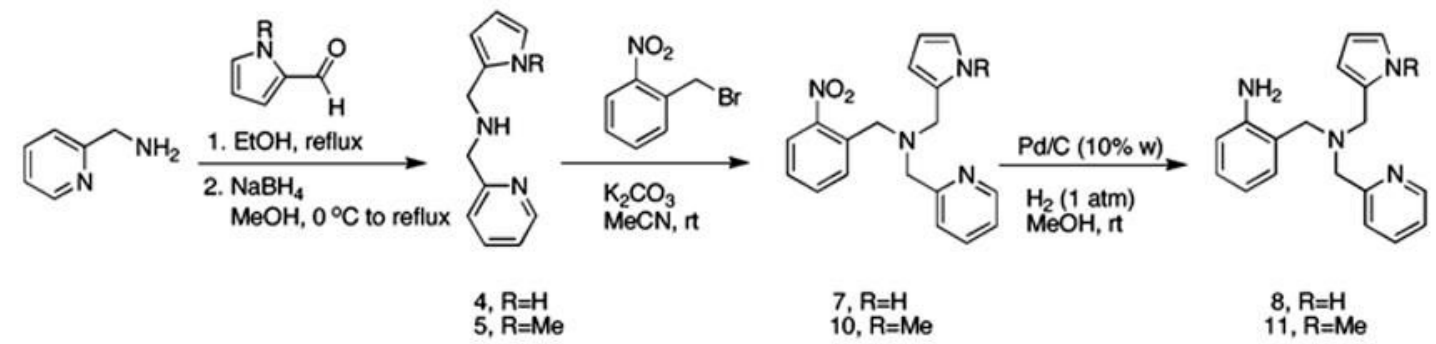

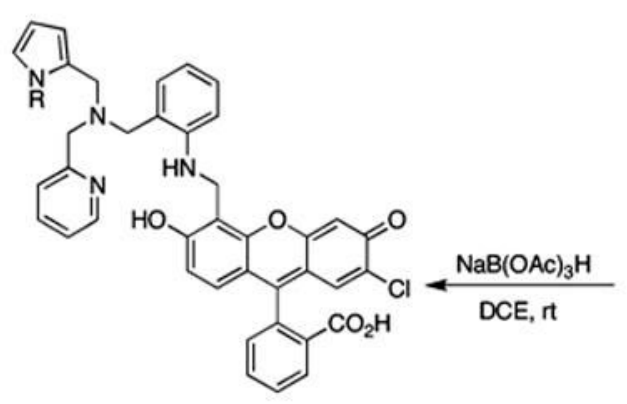

2, R=H, ZP9 3, $\mathrm{R}=\mathrm{Me}, \mathrm{ZP} 10$

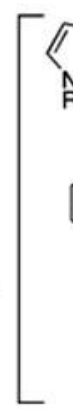<smiles></smiles>

9, $\mathrm{R}=\mathrm{H}$

$8 . \mathrm{P}=\mathrm{H}$

$11, \mathrm{R}=\mathrm{Me}$

Scheme 1.

Syntheses of ZP9 and ZP10 
<smiles></smiles>

6<smiles>Nc1ccccc1</smiles>

1. EtOAc, it

2. $\mathrm{NaB}(\mathrm{OAC})_{3} \mathrm{H}$ DCE, $\mathrm{rt}$

Scheme 2.

Synthesis of Compound $\mathbf{1 3}$ 

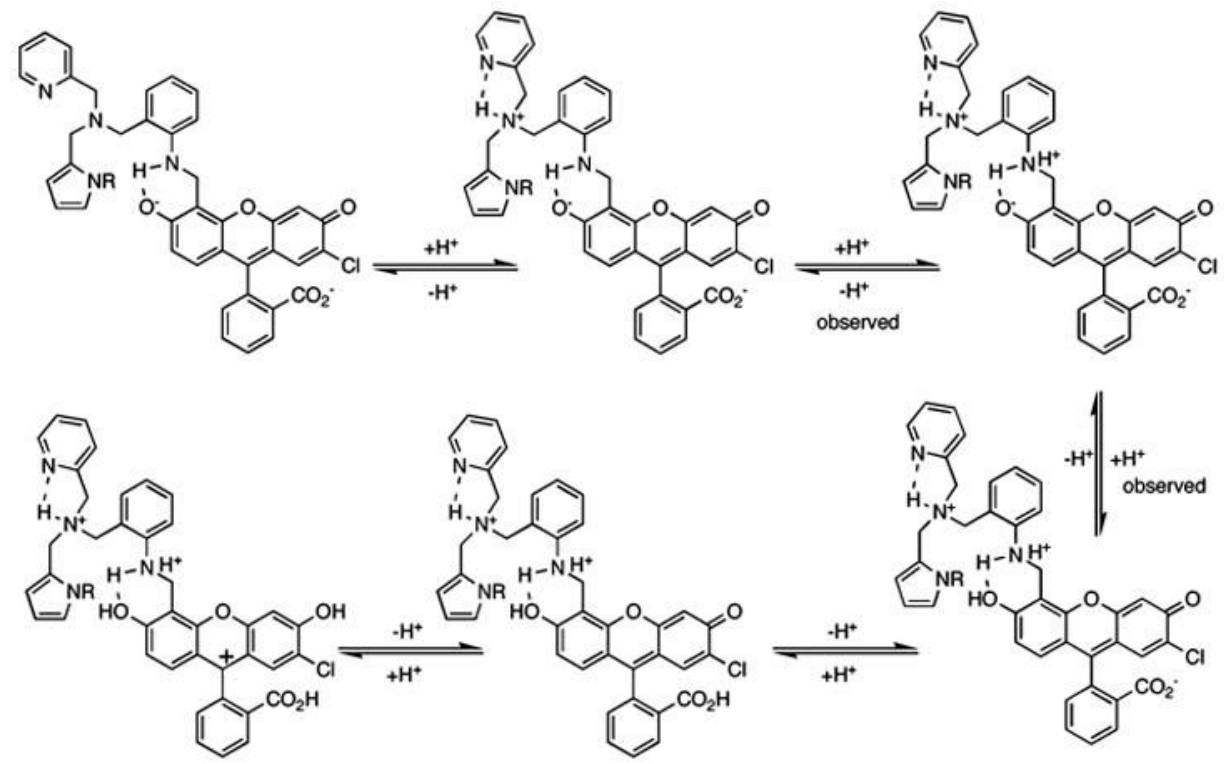

${ }^{a}$ Observed indicates that the protonation event is detectable by fluorimetric titration in the pH range of $\sim 12$ to $\sim 3$.

\section{Scheme 3.}

Proposed Protonation Equilibria for ZP9 and ZP10 ${ }^{a}$

${ }^{a}$ Observed indicates that the protonation event is detectable by fluorimetric titration in the $\mathrm{pH}$ range of $\sim 12$ to $\sim 3$. 
Table 1

Spectroscopic and Thermodynamic Data for Several Asymmetrical Zn(II) Sensors ${ }^{a}$

\begin{tabular}{|c|c|c|c|c|c|c|c|}
\hline & \multicolumn{2}{|c|}{$\begin{array}{c}\text { absorption } \lambda(\mathrm{nm}), \varepsilon\left(\times 10^{4} \mathrm{M}^{-1}\right. \\
\left.\mathrm{cm}^{-1}\right)\end{array}$} & \multicolumn{2}{|c|}{ emission $\lambda(\mathbf{n m}), \Phi^{b}$} & \multirow[b]{2}{*}{$\begin{array}{c}\mathbf{p} K_{\mathrm{a}}^{c} \\
(\mathbf{N})\end{array}$} & \multirow[b]{2}{*}{$\mathrm{p} K_{\mathrm{a}}^{d}$} & \multirow[b]{2}{*}{ ref } \\
\hline & unbound & $\mathrm{Zn}(\mathrm{II})$ & unbound & $\mathrm{Zn}(\mathrm{II})$ & & & \\
\hline $\begin{array}{l}\mathrm{ZP4}{ }^{e} \\
\mathrm{ZP} 9 \\
\mathrm{ZP} 10 \\
\mathrm{ZS} 4 \\
\text { QZ1 }\end{array}$ & $\begin{array}{l}506,6.1 \\
505,5.1 \\
506,5.5 \\
507,8.1 \\
505,6.9\end{array}$ & $\begin{array}{l}495,6.7 \\
495,4.4 \\
497,4.5 \\
495, \text { nd } \\
498,7.0\end{array}$ & $\begin{array}{l}521,0.06 \\
526,0.02 \\
523,0.08 \\
522,0.12 \\
524,0.024\end{array}$ & $\begin{array}{l}515,0.34 \\
521,0.41 \\
516,0.33 \\
520,0.50 \\
524,0.78\end{array}$ & $\begin{array}{l}7.2 \\
7.2 \\
7.0 \\
7.6 \\
6.1\end{array}$ & $\begin{array}{l}4.0 \\
5.0 \\
4.8 \\
5.1 \\
5.0\end{array}$ & $\begin{array}{l}21 \\
\text { this work } \\
\text { this work } \\
32 \\
33\end{array}$ \\
\hline
\end{tabular}




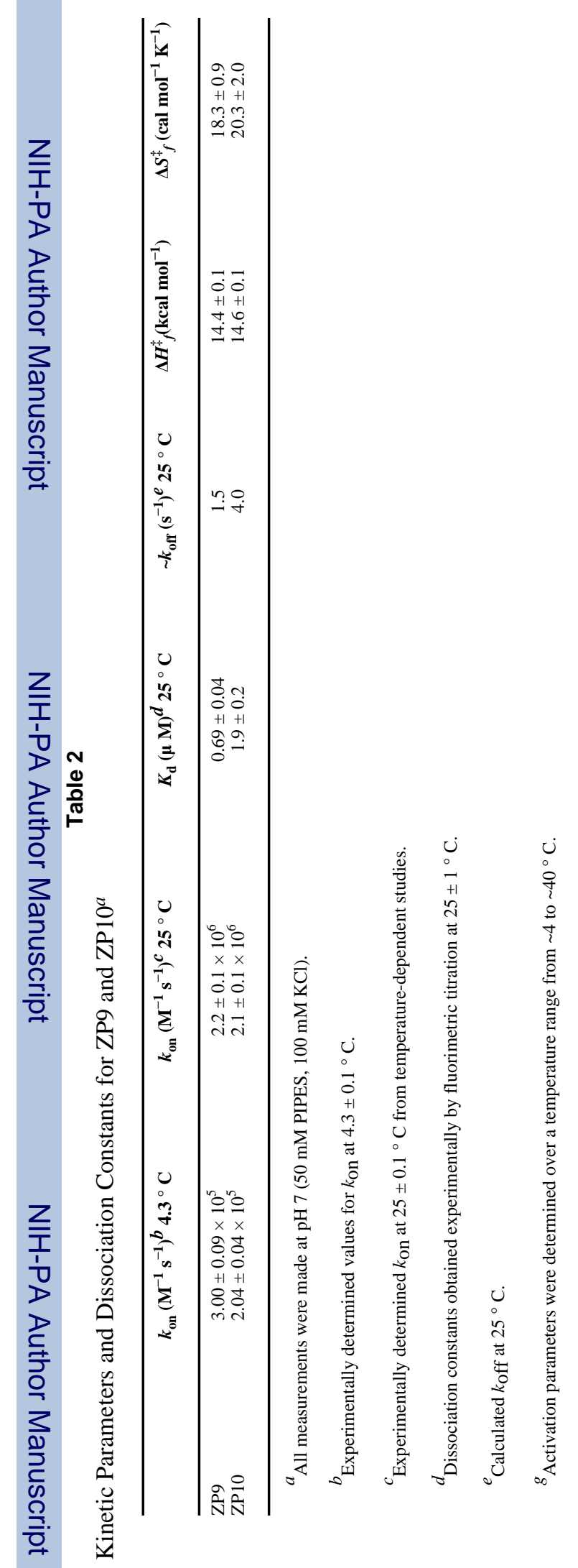

